\title{
AFTER THE HAMMER: SIX YEARS OF MEADS V. MEADS
}

\author{
DONALD J. NETOLITZKY*
}

\begin{abstract}
This article addresses the phenomenon of Organized Pseudolegal Commercial Arguments $(O P C A)$ through a retrospective investigation of Meads v. Meads. The author begins by discussing whether Meads has met its objectives, and then proceeds with an analysis of the response to the Meads decision by various audiences, including courts, academics, the OPCA community, and the public. Then, the author examines Meads as a unique type of judgment that incorporates court knowledge as its foundation, allowing Meads, in part, to offer guidance to trial court judges. Finally, the author comments on the insight offered by Meads into the day-to-day realities faced by trial courts as they interact with selfrepresented individuals.
\end{abstract}

\section{TABLE OF CONTENTS}

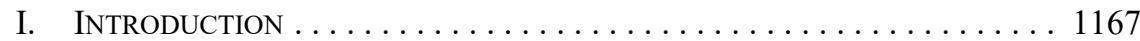

II. MEADS As A Court DeCISION ........................ 1169

A. CAPturing the OPCA Phenomenon $\ldots \ldots \ldots \ldots \ldots \ldots .1170$

B. MEADS' UnUSUAL CONTINUING

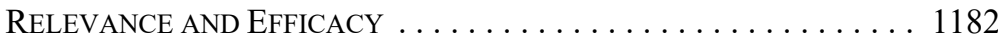

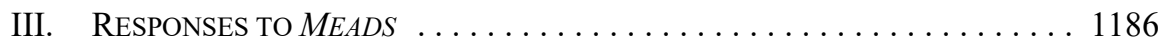

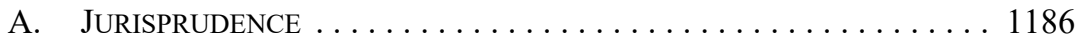

B. ACADEMIC ............................... 1189

C. THE OPCA COMMUNities ReSPOND to MEADS . . . . . . . . 1192

D. Public Response . . . . . . . . . . . . . . . . . . . . . . . . . . 1199

E. MEADS' Social EfFect . . . . . . . . . . . . . . . . 1201

IV. MEAdS ILlustrates Trial COURT EXPERTISE $\ldots \ldots \ldots \ldots \ldots \ldots \ldots$

V. What Lies AHEAD . . . . . . . . . . . . . . . . . . . . . . . . . 1205

\section{INTRODUCTION}

On 19 September 2012, Associate Chief Justice Rooke of the Alberta Court of Queen's Bench issued Meads v. Meads, ${ }^{1}$ a very unusual, and arguably unprecedented, 736-paragraph decision in response to, of all things, an application to move a contentious divorce matter into case management. Case management was, in fact, granted, but, more importantly, Meads also responded to a collection of unorthodox documents and arguments advanced by the husband, Dennis Larry Meads. He purported to name the case management justice his fiduciary, unilaterally imposed a scheme of fines on anyone who would interact with him or use his name, and detailed a contract between himself (DENNIS LARRY MEADS) and himself(::Dennis-Larry: Meads::), which said Mr. "Meads" could pay his spousal and child support obligations from Mr. "MEADS" \$100 billion dollar public treasury bank account. Needless to say, this was all nonsense.

PhD Microbiology, University of Alberta, 1995; LLB, University of Alberta, 2005. Complex Litigant Management Counsel for the Alberta Court of Queen's Bench. The views expressed in this article are those of the author, and not those of any other member of the Court of Queen's Bench, or the Court itself.

2012 ABQB 571 [Meads]. 
Nevertheless, this was not unique nonsense, and so the Court responded to Mr. Meads with a decision that compiled over a decade of Canadian jurisprudence, American academic research, and the Court's own encounters with persons who held beliefs parallel to those of Meads. Meads described and refuted a collection of concepts grouped under a novel label: "Organized Pseudolegal Commercial Arguments" (OPCA). These ideas are pseudolaw, a collection of motifs that sound like law and often involve legal terminology, but which lead to legally incorrect results. Most pseudolaw is designed to defeat or bypass state, police, court, and institutional authority. ${ }^{2}$

In the most restricted sense, Meads did its job. Meads abandoned his OPCA concepts, retained counsel (for a time), and, while the Meads' divorce was only finalized on 4 April 2017 , in the intervening period the action continued and ended in a manner that complied with Canadian law.

This decision, however, had a broader objective. Meads was designed as a one-stop resource for courts facing persons who advance OPCA schemes. The goal was more than to simply collect and rebut pseudolaw, but also to provide a field guide to recognize these people, document and explain the strange ways OPCA litigants operate, their curious misuse of legal language and concepts, and to open a window into the communities and personalities that drove this phenomenon. This is a business where secret "cheat codes" and "get out of jail free" cards are marketed to a gullible, often conspiracy-driven, customer base. ${ }^{3}$

Meads was designed to be comprehensive. Up to this point, the OPCA phenomenon, its pseudolaw, and sub-societies were all but undocumented, and known only to trial court judges in those locations where OPCA litigants were active ${ }^{4}$ and a few specialized types of litigators. $^{5}$

This article shows, in that broader sense, that Meads again was successful. This decision is a much-referenced resource to understand and then respond to the abusive litigants who use OPCA strategies. The OPCA community perceives Meads as a serious threat and obstacle.

2 Donald J Netolitzky, “Organized Pseudolegal Commercial Arguments in Canadian Inter-Partner Family Law Court Disputes" (2017) 54:4 Alta L Rev 955 at 993-94 [Netolitzky, "Family"]; Donald J Netolitzky, "A Rebellion of Furious Paper: Pseudolaw as a Revolutionary Legal System" (Paper delivered at the CEFIR Symposium Sovereign Citizens in Canada, 3 May 2018) at 5-7 [unpublished] [Netolitzky, "Rebellion"], online: researchgate <www.researchgate.net/publication/325053364_A_ Rebellion of Furious Paper Pseudolaw as a Revolutionary Legal System>.

3 Donald J Netolitzky, "The History of the Organized Pseudolegal Commercial Argument Phenomenon in Canada" (2016) 53:3 Alta L Rev 609 at 635-36 [Netolitzky, "History"]; Donald J Netolitzky \& The Honourable Associate Chief Justice John D Rooke, "Organized Pseudolegal Commercial Argument [OPCA] Litigants: New Challenges in the Internet Age" (Paper delivered at the CIAJ National Roundtable on the Vexatious Litigant, Toronto, 10 March 2016) at 11-14; Netolitzky, "Family," ibid at $992-93$.

4 Edmonton, Alberta, was and remains a hotspot for OPCA activities, and is the home of several gurus, including "minister" Belanger of the Church of the Ecumenical Redemption International and "rob in the pagé family," also known as "White Walking Feather." See Meads, supra note 1 at paras 134-39, 183-88; rob in the pagé family, Graduating Life with Honours: Conscious Self-Governance in God's Kingdom (self-published, 2015), online: Steemit <https://steemit.com/peace/@wwf/graduating-life-withhonours-conscious-self-governance-in-god-s-kingdom>.

OPCA litigation chiefly addresses four topic areas: (1) tax evasion; (2) "get out of jail free" strategies; (3) debt elimination; and (4) spurious attacks on institutions and state organs: Netolitzky, "Family," supra note 2 at 957-58; Netolitzky, "Rebellion," supra note 2 at 6-7. 
But, unexpectedly, Meads has become more. Meads is that most exotic of creatures - a court judgment read by the public for educational and informational purposes. Maclean's magazine described Meads as a "Court decision with a cult following." Any Internet search will identify Meads referenced in a diverse range of online forums. This decision has become a principal reference for academics, and is also cited as a restatement for broader principles of law. This is unexpected for any court decision, let alone one from a trial-level court.

This article conducts a retrospective investigation of Meads:

1. Did Meads meet its stated objectives? Has the passage of time brought to light gaps or errors in its content and analysis? If so, to what degree are those deficiencies addressed by subsequent jurisprudence?

2. What has been the response to Meads from:

(a) courts in Canada and elsewhere;

(b) legal academics and academics in other disciplines;

(c) the OPCA community and its leadership; and

(d) the general public.

Last, this article asks a broader question. Ultimately, Meads' utility builds off a foundation of court knowledge. Trial courts are not usually viewed as the locus where legal expertise resides, but Meads suggests that sometimes is the case. If so, is Meads a type example of a new category of judgment, and, if so, where and when might this kind of judgment emerge?

\section{MEADS AS A COURT DECISION}

In certain ways, Meads is an ordinary trial-level decision. It states facts concerning the litigation, reviews the relevant law, then applies that law to these specific facts. What makes this decision exceptional is a broader investigation that:

1. reviews facts related to the OPCA phenomenon, either known to the Court, disclosed in other reported judgments, or otherwise before the Court;

2. conducts a broad-based review of pre-existing decisions that respond to OPCA strategies;

3. classifies OPCA strategies and develops a standard terminology for these concepts; and 
4. identifies broad principles of law that relate to and refute OPCA litigation. $^{7}$

Meads' target audience is also unusual. Meads was not simply intended as a resource for legal professionals, but also speaks directly to those who use and promote OPCA concepts. ${ }^{8}$ This decision was intended as a cohesive reply to this emerging brand of abusive and vexatious litigation.

Meads largely met its stated objectives. However, the decision was, in certain ways, hampered by the information resources on which it was based. This led to a number of gaps.

\section{A. Capturing the OPCA Phenomenon}

Meads was intended to describe the OPCA phenomenon in a comprehensive manner. Associate Chief Justice Rooke explicitly indicated that in addition to reported jurisprudence, he relied upon other information sources: (1) the unusually comprehensive and detailed materials filed by Meads $;^{9}$ (2) the Alberta Court of Queen's Bench's own direct interactions with OPCA litigants in other matters; and (3) irregular correspondence received by the Court. ${ }^{10}$ In brief, the Court took judicial notice of this information and these experiences.

\section{WHAT IS THE OPCA PHENOMENON?}

Meads reviews what it calls the "OPCA Phenomenon," notes the remarkable diversity of persons who adopt and apply pseudolaw, ${ }^{11}$ and then identifies from that population a leader/teacher caste, "gurus," 12 and subcommunities, "movements." 13 Six years later this survey remains a highly useful description of the OPCA phenomenon and has not been the subject of any substantive criticism. That said, Meads' profile of the OPCA phenomenon has some factual issues and limitations.

One error in Meads is that the Freemen-on-the-Land were described as being "strongly anti-government" with "libertarian and right wing overtones. Christian rhetoric is common." 14 Subsequent investigation, including a recent sociological profile of this population, has instead concluded that while this community is indeed extremely hostile to state and institutional actors, politically this population is predominately "left leaning." 15 The

Meads, supra note 1 at paras 60-65.

Ibid at paras 66, 663-75.

Some of Dennis Meads' documents are reproduced in the decision as Appendix A and B. This practice of incorporating OPCA materials into decisions is a useful, efficient, and increasingly common method to report OPCA strategies. See e.g. Bossé v Farm Credit Canada, 2014 NBCA 34, leave to appeal to SCC refused, 36026 (11 December 2014) [Bossé]; Alberta Treasury Branches v Nielson, 2014 ABQB 383 [Nielson]; Re Boisjoli, 2015 ABQB 629 [Boisjoli]; Servus Credit Union Ltd v Parlee, 2015 ABQB 700 [Parlee]; Pomerleau v Canada (Revenue Agency), 2017 ABQB 123 [Pomerleau]; Re Gauthier, 2017 ABQB 555; Knutson (Re), 2018 ABQB 858 [Knutson].

Meads, supra note 1 at paras 53-57.

Ibid at paras $67-80$.

Ibid at paras $85-158$.

Ibid at paras 159-98.

Ibid at para 172 .

Canadian Network for Research on Terrorism Security and Society, "Broadening Our Understanding of Anti-Authority Movements in Canada," by Barbara Perry, David C Hofmann \& Ryan Scrivens, Working Paper No 17-02 (Ontario: TSAS, August 2017) at 21-24, 29-30 [TSAS, "Broadening Our Understanding"]. See also Netolitzky, "History," supra note 3 at 624-27. 
central influence of Christian concepts and perspectives was also overstated. The Freemen are less an organization or "movement" than a collection of individuals who hold powerful anti-authority beliefs, but are otherwise ideologically heterogeneous. ${ }^{16}$ Their motivation to investigate and apply pseudolaw varies. ${ }^{17}$ The amorphous character of the Freeman population and the broad overlap between Freeman and Sovereign Citizen OPCA theories explains the Meads mischaracterization, which apparently confused these two populations. ${ }^{18}$

Another factual issue is that descriptions of the Church of the Ecumenical Redemption International (CERI) pseudolaw are unfocused, ${ }^{19}$ though that is unsurprising, given the incoherent document style of this group. A better review of CERI's theories can be found in more recent jurisprudence ${ }^{20}$ and the many YouTube videos of its guru, "minister" "paraclete" Edward Jay Robin Belanger. ${ }^{21}$

Certain important personalities and groups were not identified. For example, no mention is made of Freeman-on-the-Land guru Dean Christopher Clifford. ${ }^{22}$ The Freeman-on-theLand movement was essentially the sole construct of former street comedian Robert Arthur Menard. Menard was the dominant, if not only, leadership figure from 2000-2010. ${ }^{23}$ However, after that point Menard was increasingly challenged by Clifford, who advocated a more confrontational "muscular" approach to Freemanism. ${ }^{24}$ In fact, Meads was written when Clifford was approaching the zenith of his status as a pseudolaw guru. Clifford's reputation as an effective leader and information source collapsed following his 2013 arrest at the conclusion of an OPCA seminar in Hamilton, Ontario ${ }^{25}$ and a subsequent 2015 conviction and three-year sentence for drugs and firearms offences. ${ }^{26}$ Clifford now appears to be re-entering the OPCA guru marketplace. ${ }^{27}$

Similarly, Meads does not report on the then active Sovereign Squamish Government and Tacit Supreme In Law Courts / United Sovran Nation (TSILC/USN) OPCA movements. ${ }^{28}$

TSAS, "Broadening Our Understanding," ibid at 20-25, 29-30.

Ibid at 34-45. See also Donald J Netolitzky, "Organized Pseudolegal Commercial Arguments [OPCA] in Canada; An Attack on the Legal System" (2016) 10 JPPL 137 at 175-82 [Netolitzky, "Attack"].

TSAS, "Broadening Our Understanding," ibid at 15 observes a broad influence between these groups, and at 23 one of the paper's authors, David Hofmann, has concluded the Sovereign Citizen and Freeman populations share ideological links relating to alleged state corruption and infringement on rights, citing David C Hofmann, "Breaking Free: A Socio-Historical Analysis of the Canadian Freeman-on-the-Land Movement" in J Littlewood, L Dawson \& S Thompson, eds, Canada Among Nations (Toronto: University of Toronto Press, forthcoming). Ryan Scrivens \& Barbara Perry, "Resisting the Right: Countering Right-Wing Extremism in Canada" (2017) 59:4 Can J Corr 534 at 553; Canadian Network for Research on Terrorism, Security and Society, "The Future of Right Wing Terrorism in Canada," by Richard B Parent \& James O Ellis III, Working Paper No 16-12 (Ontario: TSAS, July 2016) at 17-18 also group the Freemen-on-the-Land community with right-wing extremists.

Meads, supra note 1 at paras 134-39, 183-88.

Potvin (Re), 2018 ABQB 652 at paras 102-34 [Potvin].

See paraclete Edward Jay Robin, online: YouTube $<$ https://www.youtube.com/user/Owlmon>.

See Scotia Mortgage Corporation v Landry, 2018 ABQB 951 at paras 40-60 [Landry].

Netolitzky, "History," supra note 3 at 624-26; TSAS, "Broadening Our Understanding," supra note 15 at $13-16$.

Netolitzky, "History," ibid at 626-27; TSAS, "Broadening Our Understanding," ibid at 16-18.

This arrest was a watershed moment for the Freeman-on-the-Land movement that made plain the impotence of Freeman concepts. The arrest was video recorded by attendees: Shock Diamond, "Original Dean Clifford Kidnapped November 24, 2013 at the Mariott Courtyard Hamilton” (24 November 2013), online: YouTube $<\mathrm{https}$ ://www.youtube.com/watch? $\mathrm{v}=\mathrm{hsSO}$ OGHjII $>$.

$R v$ Clifford (12 January 2016), Winnipeg CR14-01-33786 (Man QB).

Landry, supra note 22.

Netolitzky, "History," supra note 3 at 628-29. 
These omissions are explained by the fact that neither Clifford, the Sovereign Squamish Government, nor TSILC/USN were identified in reported pre-2012 court decisions.

Meads has other significant factual lacunae. Meads failed to detect early OPCA litigation, ${ }^{29}$ which extends back to at least the 1950s. This omission occurred even though many arguments advanced during this "Pre-Detaxer" period ${ }^{30}$ were reused and rejected in subsequent OPCA jurisprudence. Some key Pre-Detaxer litigation occurred in the Alberta Court of Queen's Bench itself. ${ }^{31}$

Meads makes only a notational effort to link Canadian pseudolaw communities and concepts to their United States predecessor, the Sovereign Citizens, and the more recent sibling urban African-American Moorish Law communities. In fairness, any such attempt would have almost certainly failed since there still is no accessible broad scope reference that reliably details these groups, their history, and concepts. Far fewer potentially useful sources existed in 2012.

Similarly, Quebec OPCA activities are all but undocumented. Meads identifies only one OPCA-related case from that jurisdiction: Services de financement TD inc. c. Michaud. ${ }^{32}$ This is a significant gap in Meads' planned comprehensive survey of the relevant jurisprudence. Less than 2 percent $(n=70)$ of OPCA case law from Quebec was identified. Meads did not detect a large US-style "A4V" "money for nothing" operation that was then underway in that province, ${ }^{33}$ as well as substantial Quebec Detaxer activities, led by figures such as Christian Fréchette ${ }^{34}$ and Jacques Joseph Pierre Antoine Normandin. ${ }^{35}$

The limited reporting of Quebec OPCA litigation reflects a broader pattern. Meads identified 149 Canadian OPCA-related judgments. Further investigation has identified an additional 384 pre-Meads OPCA-related judgments. Meads only captured a little over a quarter of the potentially relevant jurisprudence. That estimate is probably too high.

The earliest OPCA-related decision cited in Meads is Giagnocavo v The Queen (1995), 95 DTC 5650 (FC(TD)), appeal abandoned (17 December 1997), Toronto A-628-95 (FCA): see Meads, supra note 1 at para 340. This is only one of two pre-2000 OPCA-related cases identified in Meads.

Netolitzky, "History," supra note 3 at 613-16.

$31 \quad R v$ Gavreau (19 June 1995), Grande Prairie 9404-0009S20101 (Alta QB); $R$ v Strang (DG) (1997), 207 AR $72(\mathrm{QB})$.

2011 QCCQ 14868.

Netolitzky, "History," supra note 3 at 631-32; Bossé, supra note 9. At least one lawyer and two notaries participated in this scheme: Donald J Netolitzky, "Lawyers and Court Representation of Organized Pseudolegal Commercial Argument [OPCA] Litigants in Canada" (2018) 51:2 UBC L Rev 419 at 460-63 [Netolitzky, "Lawyers"]; Notaires (Ordre professionnel des) c Lalonde, 2014 CanLII 47759 (Chambres de Notaires Qc); Bossé, supra note 9 at Appendix B.

34 Québec (Sous-ministre du Revenu) c Bergeron, 1998 CanLII 10968 (QCCQ); Québec (Sous-ministre du Revenu) c Fréchette, 1998 CanLII 10993 (CQ crim \& pén); Fréchette c R, 2002 CanLII 6614 (QCCS).

35 Representing himself: Dubois Coulombe c Agence du revenu du Québec, 2012 QCCS 67; Dubois Coulombe c Agence du revenu du Québec, 2012 QCCS 71; Normandin c Caisse Populaire de Alma, 2003 CanLII 49054 (CQ civ); Normandin c Banque Royale du Canada, 2003 CanLII 54397 (CQ civ); Normandin c Étude d'avocats Desjardins Ducharme Stein Monast, 2004 CanLII 25065 (CQ civ); Normandin c Étude d'avocats Desjardins Ducharme Stein Monast, 2004 CanLII 26146 (CQ civ); Normandin c Le Conseil Canadien de la Magistrature, 2004 CanLII 45928 (CQ civ). Acting as a litigation representative: Pelletier c Bergman, 2006 QCCS 1360; R c Normandin, 2005 CanLII 24311 (QCCS); R c Normandin, 2005 CanLII 24313 (QCCS); Canada (Procureur général) c Gilbert, 2006 QCCQ 24225; Bergeron c Golf de l'Estrie inc, 2010 QCCS 2146; Caisse Desjardins de la région de Mégantic c Dubois, 2012 QCCS 2907, aff'd 2012 QCCA 1893. 
Additional pre-19 September 2012 OPCA-related case law almost certainly remains unidentified.

This observation has two explanations. First, Meads was prepared on a restricted timeline. That decision was researched and written in a little over three months. Second, OPCA case law can be very difficult to locate. ${ }^{36}$ Prior to Meads, no standard label identified this litigation category. ${ }^{37}$ Many judges were unaware that what appeared to be an idiosyncratic litigant was instead an instance of a broader phenomenon. Nor do convenient clues or cues flag these cases. $^{38}$

The more important question is whether that incomplete survey of the relevant case law interfered with Meads' intended objectives. In most senses it did not.

\section{RECOGNITION OF OPCA LITIGATION AND LITIGANTS}

Part V of Meads reviews the indicia of OPCA concepts and litigants. These are "telltale fingerprints" of OPCA litigation, such as atypical name structures, OPCA-specific language and document motifs, and peculiar but unique ways that OPCA litigants conduct themselves in court. Meads then suggests procedural steps a court might take to minimize the problematic aspects of suspected OPCA litigation identified in this manner. ${ }^{39}$

This part of Meads has proven complete and accurate, and remains highly relevant. These "formal trappings" of OPCA activities remain almost entirely unchanged. Canadian courts continue to receive documents that clearly exhibit long-established, though denounced, OPCA formalities. The only notable post-2012 document indicia are the characteristic, but meaningless, manner in which followers of US guru Carl (Karl) Lentz identify themselves in civil actions as "i: a man" and as "prosecutors," and that they are "legal idiots" or "idiots to legalese." 40

The recent Alberta Court of Queen's Bench Re Gauthier ${ }^{41}$ decision illustrates how OPCA indicia may guide pre-emptive Court intervention. Re Gauthier reports a challenge by persistent Freeman litigant Adam Christian Gauthier to traffic tickets Gauthier received after he drove a motor vehicle without a licence, insurance, and registration, and for displaying a licence plate that read "private non commercial use only." These illegal OPCA activities are often called "travelling," based on a spurious distinction between "driving," which is

Netolitzky, "Family," supra note 2 at 964-65.

Ibid. This situation continues at present. Only a small fraction (33.6 percent, $\mathrm{n}=172$ ) of post-19 September 2012 judgments that report on disputes that involve OPCA concepts reference Meads.

Netolitzky, "Family," ibid at 964-65.

Meads, supra note 1 at paras 254-63.

Gauthier v Starr, 2016 ABQB 213 at paras 29-34 [Starr]; Taraba v Erwin, 2017 ONSC 5788; Parker $v$ McKenna \& Anor, [2015] NIMaster 1 at para 3; $R v d$ 'Abadie, 2016 SKQB 101 at paras 12, 15, aff'd 2016 SKCA 72 [d'Abadie \#1], leave to appeal to SCC refused, 37507 (28 September 2017); SS (Re), 2016 ABPC 170 at paras 9-10; Netolitzky, "History," supra note 3 at 631.

$41 \quad$ Supra note 9 at paras 3-8. 
regulated by legislation, and "travelling," which is (allegedly) an absolute common law right. $^{42}$

The Alberta Court of Queen's Bench clerks rejected Gauthier's attempts to file OPCA materials on the basis of a 2013 "Master Order for Organized Pseudolegal Commercial Argument ('OPCA') Documents," which prohibited filing of documents that exhibit meaningless but unique pseudolaw motifs. One such formal defect in Gauthier's materials were duplicate personal names, where one variation is in all capital letters. ${ }^{43}$ This, allegedly, identifies the "Strawman" legal fiction doppelganger. ${ }^{44}$ Gauthier was denied a fiat to file, declared a vexatious litigant, and prohibited from filing or continuing actions in Alberta Courts except with leave. ${ }^{45}$

Whether other Canadian courts have implemented analogous procedures is not known. The Alberta approach is by all reports highly effective. This early response mechanism ended 95 percent of attempts to initiate OPCA-based litigation. ${ }^{46}$ Similarly, half of Alberta Court of Queen's Bench OPCA litigants abandoned their pseudolegal strategies after post-filing, but pre-emptive, court review and rejection of OPCA documents. ${ }^{47}$

The Meads OPCA indicia serve another useful role not suggested in that decision. Psychiatric investigation of Freemen and Sovereign Citizens has concluded adherence to pseudolaw conspiracies is an expression of extreme political beliefs, reinforced in small introspective social communities ${ }^{48}$ However, the peculiar formulaic expression of these ideas mimics delusion. That has resulted in misdiagnosis of these persons as mentally ill. OPCA ideas such as the "Strawman" duality have been misidentified as a mental health issue, rather

Comprehensively reviewed and rejected: d'Abadie v Her Majesty the Queen, 2018 ABQB 298 at paras 71-87 [d'Abadie \#2]. OPCA texts: David Kevin Lindsay, Rights Denied! How Your Government Has Stolen Your Right to Use Your Highways You Pay For! (Winnipeg: AaA Publishing, 1999); Charles A Weisman, The Right to Travel (Liberty or License?), 4th ed (Apple Valley, Minn: Weisman Publications, 2005).

43 Meads, supra note 1 at paras 211-12.

44 Donald J Netolitzky, "Organized Pseudolegal Commercial Arguments As Magic and Ceremony" (2018) 55:4 Alta L Rev 1045 at 1069-78 [Netolitzky, "Magic"]. This motif is also called the double/split person: Meads, supra note 1 at paras 417-46.

45 Re Gauthier, supra note 9 at paras 69-93. See also Toronto-Dominion Bank v Leadbetter, 2018 ABQB 472 at para 12 [Leadbetter]; Alberta Treasury Branches $v$ Hawrysh, 2018 ABQB 475 at para 1 [Hawrysh $\# 1]$.

$46 \quad$ Netolitzky, “Attack,” supra note 17 at 184-85; Netolitzky \& Rooke, supra note 3 at 29-30.

Netolitzky \& Rooke, ibid at 30-31.

Jennifer Pytyck \& Gary A Chaimowitz, "The Sovereign Citizen Movement and Fitness to Stand Trial" (2013) 12:2 Intl J Forensic Mental Health 149. See also George F Parker, "Competence to Stand Trial Evaluations of Sovereign Citizens: A Case Series and Primer of Odd Political and Legal Beliefs" (2014) 42:3 J American Academy Psychiatry \& L 338; Cheryl M Paradis, Elizabeth Owen \& Gene McCullough, "Evaluations of Urban Sovereign Citizens' Competency to Stand Trial" (2018) 46:2 J American Academy Psychiatry \& L 158. 
than pseudolaw. ${ }^{49}$ Court-ordered psychiatric examinations and detentions may result. ${ }^{50}$ The Meads OPCA indicia are therefore a helpful resource to distinguish between persons who litigate because of mental illness versus anti-government ideology expressed in an unorthodox manner.

\section{DESCRIPTION OF OPCA CONCEPTS}

Meads was intended to capture, review, describe, and debunk Canadian pseudolaw. Again, in this sense, Meads was largely successful, but with one particular shortcoming. Meads' survey breaks OPCA motifs into five major categories or schemes, that:

1. defeat or restrict court authority ("Magic Hats");

2. consider everything is a contract;

3. stipulate silence means consent;

4. involve the "Strawman" duality; and

5. provide "money for nothing," chiefly "Accept for Value" or "A4V."

The description and classification used to explain the first four subtypes have been largely accepted though certain terminology used in Meads, like "Magic Hats" and the "double/split person," has not caught on.

However, the last "money for nothing" category is incomplete. Meads discusses three "money for nothing" schemes. A4V purports to make payments out of a fictitious government-operated bank account. Associate Chief Justice Rooke observed that the process behind this scheme simply does not make sense, so he described this as an "unlocking spell." 52 The New Brunswick Court of Appeal in Bossé v. Farm Credit Canada ${ }^{53}$ came to essentially the same conclusion during its review of the 2011-2013 Quebec-based A4V ring: A4V "defies logic." ${ }^{54}$ Meads then briefly describes schemes that misapply the Bills of Exchange Act, ${ }^{55}$ and a curious concept that banks create money "out of thin air." Earlier,

Netolitzky, “Attack," supra note 17 at 168-71, examines Rodney King, who was potentially misdiagnosed and sentenced as not criminally responsible. King remains detained in a psychiatric facility over ten years after he, while being evicted, ambushed and shot a police officer: King (Re), [2017] ORBD No 912 (Ont Review Board); $R$ v King, 2018 ONCJ 190. NM, 2011 CanLII 73645 (Ont Consent and Capacity Board); $J B$ (aka PS) (Re), 2015 CanLII 92039 (Ont Consent and Capacity Board); Fortin-Girard v Monteith Correctional Facility, 2013 HRTO 1748 (CanLII) are other decisions which report psychiatric detention of persons who exhibit OPCA indicia. Mental health professionals subsequently recognized the political and pseudolegal character of Fortin-Girard's beliefs, but detention was continued: $J A G$ (Re), 2014 CanLII 32619 (Ont Consent and Capacity Board). JB's OPCA motifs were immediately identified as unorthodox political statements, rather than delusion.

$50 \quad$ See e.g. $R$ v Leis, 2004 SKQB 157 at para 5; $R$ c LK, 2010 QCCQ 3694 at paras 16, 33, rev'd 2011 QCCA 803 at paras 2-3; Fidler v Forensic Psychiatric Institute, a Hospital, 2015 BCSC 1241, aff'd 2016 BCCA 83.

Meads, supra note 1 at paras 267-378, 379-416, 447-528, 417-46, 529-50, respectively.

Ibid at para 537.

Bossé, supra note 9.

Ibid at para 42 .

RSC 1985, c B-4 [BEA]. 
Meads also described how foisted unilateral agreements may (allegedly) be used to discharge debts. ${ }^{56}$

Meads also did not identify a rich vein of pseudolaw designed to defeat bank or lender authority in a manner analogous to how "Magic Hats" supposedly place OPCA litigants outside court jurisdiction. These include, for example:

- a requirement that a lender produce an original contract with a "wet ink signature", ${ }^{57}$

- $\quad$ a contract is only valid if it is signed by witnesses; ${ }^{58}$

- $\quad$ a debt is only valid where the lender produces a "True Bill inked in blue";,59

- a debt can only be proven by bank ledger records; ${ }^{60}$

- the lender must provide evidence that the debt contract has not been sold or "securitized"; 61 and

- the lender only provided "fiat currency" or currency not backed by gold. ${ }^{62}$

OPCA debtors commonly seek to leverage these alleged defects via a highly stereotypic set of foisted unilateral agreements, documents where a failure to reply or respond in an identified manner allegedly mean the recipient has agreed. ${ }^{63}$ The lender's inadequate response allegedly creates estoppel by "tacit procuration." This process has a number of names: "the Three Letters," "the Five Letters," an "Administrative Process," or "Notary Protest" (Three/Five Letters). Meads describes how foisted unilateral agreements may,

Meads, supra note 1 at paras 487-88.

Royal Bank of Canada v Skrapec, 2011 BCSC 1827 at para 24, leave to appeal to BCCA refused, 2012 BCCA 10 [Skrapec]; Xceed Mortgage Corporation/Corporation hypothécaire Xceed c PépinBourgouin, 2011 QCCS 2116 at paras 15-18 [Pépin-Bourgouin]; Banque Royale du Canada c Tremblay, 2013 QCCQ 12827 at para 14 [Tremblay CQ], aff'd 2013 QCCA 2035 at para 7 [Tremblay CA]; Canadian Imperial Bank of Commerce v Piedrahita, 2012 NBQB 101 at para 8, leave to appeal to NBCA refused (2012), 387 NBR (2d) 399 (CA) [Piedrahita]; The Bank of Nova Scotia v Lai-Ping Lee, 2013 ONSC 6698 at para 10 [Lee]; First National Financial GP Corporation v Maritime Residential Housing Development Ltd, 2013 NSSC 219 at para 7; Toronto-Dominion Bank v Devries, 2013 CanLII 41978 (Ont Sup Ct (Sm Cl Ct)) at paras 2-3, 40-48 [Devries]; Banque Royale du Canada c Minicozzi, 2013 QCCQ 6566 at para 21, aff'd 2013 QCCA 1722; Bank of Montreal v Rogozinsky, 2014 ABQB 771 at paras 24, 41-43, 56 [Rogozinsky]; Toronto-Dominion Bankv Thompson, [2015] OJ No $5141(\mathrm{QL})$ at paras 7, 16 (Sup Ct (Sm Cl Ct)); Alberta v Greter, 2016 ABQB 293 at paras 2, 11,16 [Greter]; Royal Bank of Canada v 101000039 Saskatchewan Ltd, 2017 SKQB 253 at paras 9, 19 [Royal Bank]; Knutson, supra note 9 at Appendix E. Greter, ibid at paras 11, 16.

Ibid at paras 11, 19. Skrapec, supra note 57 at para 24.

Piedrahita, supra note 57 at paras 6, 10-11; Rogozinsky, supra note 57 at paras 24, 56; Greter, ibid at paras 2,11, 17; Knutson, supra note 9 at para 12. See also Whitfield v Chrysler Credit Canada Ltd, 2001 ABQB 5 at para 18 [Whitfield].

Skrapec, supra note 57 at para 25; Pépin-Bourgouin, supra note 57 at paras 19-20; Tremblay CQ, supra note 57 at para 15; Tremblay CA, supra note 57 at para 7; Lee, supra note 57 at para 9; Rogozinsky, ibid at paras 27-28, 44-46; Greter, ibid at paras 2, 18; Royal Bank, supra note 57 at paras 10, 21.

Skrapec, ibid at para 65; Devries, supra note 57 at paras 4, 30-36; Knutson, supra note 9 at para 66. Meads, supra note 1 at paras 447-528. 
allegedly, defeat debt collection, ${ }^{64}$ but the first decision to document the Three/Five Letters process as a whole is the 2014 Bank of Montreal v. Rogozinsky ${ }^{65}$ decision.

The Three/Five Letters are also often combined with a US-sourced conspiracy theory that flows from how most banks make loans based on reserves that are much less than total bank liabilities, what is called fractional reserve banking. This is one of the oldest pseudolegal themes, tracing to the Billions for the Bankers, Debts for the People pamphlet by 1970s Christian Identity leader Sheldon Emry. ${ }^{66}$ A Canadian variant of this document was written by Joseph A. Thauberger, a Saskatchewan Social Credit politician, who subsequently founded the Canada Party. Thauberger's version exists in several editions. ${ }^{67}$

While the underlying narrative of fractional banking conspiracy theory is quite complicated and relates to an arcane aspect of modern finance, the basic, but erroneous, claim is that banks loan nothing of value because they either create money "from thin air," or the borrower creates the money loaned via promissory note processes and his or her signature. Unlike most pseudolegal theories, this one actually has case law to support that proposition. A 1968 US Minnesota decision, First National Bank of Montgomery v. Daly, also known as the "Credit River" case, did deny bank recovery of a debt on the basis that the bank had not provided any money. ${ }^{68}$ While the Credit River case was declared a nullity and unauthorized, ${ }^{69}$ and has been rejected in Commonwealth courts, ${ }^{70}$ this is one of the few exceptional instances where a court decision stands for exactly what its pseudolaw proponents claim.

New Zealand lawyer Thomas Bloy named the combination of the Three/Five Letters process and fractional reserve banking pseudolaw the "no value provided" debt elimination scheme. ${ }^{71}$ Around 2005, British Columbia guru John Ruiz Dempsey employed no value provided to argue bank loan contracts offer no consideration; banks just create money from "thin air." 72 While Meads identified Dempsey as a guru, ${ }^{73}$ and indicated Dempsey employed an unusual debt elimination scheme,$^{74}$ the theoretical foundation of the no value provided and the Three/Five Letters process are not explained. That had to wait until the 2014

Ibid at paras 487-88, citing Gravlin v Canadian Imperial Bank of Commerce, 2005 BCSC 839 [Gravlin]. OPCA document titles in Gravlin clearly match the Three/Five Letters scheme.

Supra note 57. Rothweiler v Payette, 2018 ABQB 288 at paras 6-21 [Rothweiler \#3] concludes the Three/Five Letters scheme is so notoriously false that employing the Three/Five Letters presumptively establishes an abusive, ulterior purpose.

Michael Barkun, Religion and the Racist Right: The Origins of the Christian Identity Movement (Chapel Hill: University of North Carolina Press, 1994) at 205.

JA Thauberger, Billions for the Bankers; Debts for the People, 5th ed (Parksville: ConspiracyKing.com, undated); JA Thauberger, Billions for the Bankers; Debts for the People, 6th ed (Christopher Lake: Freedom Foundations Inc, undated) (archived copy online: Internet Archive $<$ web.archive.org/web/2016 0331230736/http://somagardens.com/billions/b-toc.htm>).

Thomas Bloy, "Pseudolaw and Debt Enforcement" [2013] NZLJ 47; "Credit River Case," online: Minnesota State Law Library <https://mn.gov/law-library/legal-topics/copy-of-credit-river-case.jsp > . The latter provides the complete file of this notorious lawsuit.

Zurn v Northwestern National Bank of Minneapolis, 284 Minn 573 (Sup Ct 1969).

Permanent Custodians Ltd v Virgin Investments Pty Ltd, [2009] VSC 429 at paras 39-50; CrossroadsDMD Mortgage Investment Corporation v Gauthier, 2015 ABQB 703 at paras 82-83 [Crossroads]; Ennis v Credit Union Australia, [2016] FCCA 1705 [Ennis]; Lion Finance Pty Ltd v Johnston, [2018] FCCA 2745 at paras 20-25 [Lion].

Bloy, supra note 68.

Gravlin, supra note 64 at para 13; Dempsey v Envision Credit Union, 2006 BCSC 750 at paras 27-30.

Meads, supra note 1 at paras 109-20.

Ibid at paras 548-50. 
Rogozinsky ${ }^{75}$ and 2015 Crossroads-DMD Mortgage Investment Corporation v. Gauthier ${ }^{76}$ decisions. An interesting aspect of the latter decision is that Crossroads responds to an Australian variation of no value provided promoted in the 1990 s by Laurence F. Hoins. ${ }^{77}$ This illustrates the international character of OPCA concepts and litigation.

Meads correctly identifies misapplication of the $B E A$ as a "money for nothing" mechanism, but offers little detail beyond that. In fact, the $B E A$ is the foundation for three distinct OPCA "money for nothing” theories.

Two "money for nothing" theories involve Part V of the $B E A$, titled "Consumer Bills and Notes." Part V creates a transaction category called a "consumer purchase,",78 and requires that a bill of exchange or promissory note that documents a consumer purchase must be marked with text: "Consumer Purchase." ${ }^{, 79}$ Failure to mark a bill of exchange or promissory note in this manner renders that document void, ${ }^{80}$ and is an offence. ${ }^{81}$ Unlike other bills of exchange, consumer purchase promissory notes are not an absolute basis for the holder to demand payment of the amounts promised. Consumer purchase notes are subject to defences and set-off. ${ }^{82}$

The purpose of the consumer purchase scheme is explained by Master Schulz in the Crossroads decision. ${ }^{83}$ These obscure provisions were enacted in 1970 to counter a scam conducted by shady retailers who used "tear-off promissory notes" to play both sides of a transaction. The retailers would require customers sign both a purchase contract and the tearoff promissory note. The retailer would then sell the promissory note to a third party (usually at a significant discount), but fail to deliver the purchased goods or provide only defective goods. Under the $B E A$, the "consumer purchaser" would have no defence when the holder of the note came to collect. However, Part V provided consumers an effective defence to that.

This legislative response was so successful that the original scam simply vanished. Virtually no cases cite the consumer purchase provisions in the following decades. This legislation was later discovered by the OPCA community, which led to two entirely different pseudolaw schemes.

The first consumer purchase scheme argues that mundane contracts are incorrectly marked consumer purchase promissory notes, which makes them void and unenforceable. The first identified examples of this motif are two pre-Meads Alberta Court of Queen's Bench judgments: Gladue v. Asset Recovery Management \& Sales ${ }^{84}$ and Whitfield v. Chrysler

Rogozinsky, supra note 57.

Crossroads, supra note 70.

Laurence F Hoins, How To Screw 'Your' Bank: Which Bank? Any Bank, 2nd ed (Nowra, NSW: selfpublished, 1992).

BEA, supra note $55, \mathrm{~s} 188$

Ibid, s $190(1)$.

Ibid, s 190(2).

Ibid, s 192.

Ibid, s 191.

Crossroads, supra note 70 at para 50.

[1997] AJ No 1251 (QL) (QB). Interestingly, the debt-avoiders in this matter were represented by lawyer Priscilla Kennedy, who recently received sharp criticism for conducting abusive litigation: 1985 Sawridge Trust v Alberta (Public Trustee), 2017 ABQB 530. 
Credit Canada Ltd. $^{85}$ These decisions and this consumer purchase variation are not documented in Meads. Whitfield clearly was an OPCA litigant. ${ }^{86}$ She was also involved in Detaxing litigation. ${ }^{87}$ The same scheme later re-emerged in Quebec over a decade later. ${ }^{88} \mathrm{As}$ Master Schulz observes in Crossroads, this misinterpretation of the consumer purchase provisions is not surprising, given this is "technical legislation" and the purpose of Part V "is not at all obvious." 89

The second consumer purchase OPCA scheme is an entirely absurd claim that signing and writing the text "Consumer Purchase" on a bill, such as a restaurant bill, transforms the bill into a payment that may be drawn from the federal government consolidated revenue fund as an "unpayable debt." This concept appears to have been invented by Elio David Di Iorio, a musician and former Toronto-area municipal counsellor, who in 2011 unsuccessfully argued before the Ontario Court of Appeal that he had paid over $\$ 176,000$ in debts in this manner. ${ }^{90}$

Despite that unpromising start, Di Iorio's concept was then, in early 2012 (pre-Meads), adopted by Freeman-on-the-Land guru Robert Menard ${ }^{91}$ as the theoretical basis for his "Association of Canadian Consumer Purchasers" (ACCP) scheme. An early video where Menard attempts to explain the basis for the ACCP illustrates he has (or feigns to have) no comprehension of the purpose of Part V of the $B E A$. It is, in general, an excellent illustration of the Freeman-on-the-Land movement's superficial and fantasy-based approach to law. ${ }^{92}$

The ACCP then went through a number of iterations ${ }^{93}$ and in 2015 was relaunched as a program where ACCP subscribers could purchase a $\$ 2,500$ debit card each month for $\$ 250 .{ }^{94}$ Unsurprisingly, and despite many customers having paid an initial preliminary $\$ 200$ "membership fee," this "Menard Card" never materialized.

A third $B E A$ pseudolegal motif purports that a debt can be discharged via a promissory note, despite the fact the maker of that note does not intend to honour it. OPCA litigants who use this scheme often quote Lord Denning in Fielding \& Platt Ltd. v. Najjar: "We have repeatedly said in this court that a bill of exchange or a promissory note is to be treated as

852001 ABQB 497.

86 Whitfield had earlier attempted to defeat debt collection by a Three/Five Letters process: Whitfield, supra note 60 .

$R v$ Whitfield, 2001 FCT 777.

Crossroads, supra note 70 at paras 61-67; Netolitzky, "History," supra note 3 at 632.

Crossroads, ibid at para 61.

Toronto-Dominion Bank v Di Iorio, 2011 ONCA 792; Alyshah Hasham, "Courts Reject Novel Way to Pay Off Bank Debt," Toronto Star (17 December 2011) GT 8, online: Internet Archive <https://web. archive.org/web/20160708060529/http://www.enlightenedperformance.com:80/about-elio-david-diiorio.html $>$. Di Iorio argued both the "produce the original contract" and fractional reserve banking conspiracy schemes.

91 Menard explicitly sources Di Iorio in an early ACCP video: mrmitee, "Canada Law Lesson: Consumer Purchases and You - Paying by Consumer Note" (13 March 2012), online: YouTube <https://www. youtube. $\mathrm{com} /$ watch? $\mathrm{v}=$ TyQSEcdY6Mc $>$.

Ibid.

See online: <https://web.archive.org/web/20130530042743/http://consumerpurchasers.ca>.

See Netolitzky, "Attack," supra note 17 at 178; website formerly hosted online: <accp-acac.ca/>. Quatloos archived two ACCP videos and a transcript of an ACCP Facebook page, online: Mediafire $<$ www.mediafire.com/file/dv7a8n1ykk9g619/ACCPACAC+ONE+web+Narrated+show_640x480 MP4.mp4 $>$; $<$ http://www.mediafire.com/file/tgh1q395w9g4z36/ACCP+PROGRESS+REPORT_640 480_MP4.mp4>;<http://www.mediafire.com/file/hddnm6x2ytdxhdc/Menard+-+Consumer-Purchases+ $\log \cdot \overline{\mathrm{pdf}}>$. 
cash. It is to be honoured unless there is some good reason to the contrary." ${ }^{95}$ The debtor then argues that an unsatisfied promissory note becomes part of the national debt, ${ }^{96}$ is paid via $\mathrm{A} 4 \mathrm{~V},{ }^{97}$ creates money via international treaties, ${ }^{98}$ or is otherwise satisfied by obscure ceremonial means. ${ }^{99}$ The Scottish Court of Sessions (Scotland's highest civil court) in 2014 rejected that a promissory note is full payment of a debt in Child Maintenance and Enforcement Commission v. Wilson. ${ }^{100}$ That decision was then subsequently adopted in Canada. ${ }^{101}$ This scheme is, in any sense, absurd. As Associate Chief Justice Rooke observed in Re Boisjoli, the inevitable result is "a conga line of promissory notes, each purporting to satisfy the debt of the note one step up the [queue]."

A final form of economic pseudolaw not covered in Meads might be described as "Extraordinary Popular Delusions and the Madness of Crowds"103 "money for nothing" schemes. These are popular but short-lived scams that promise free money or debt elimination. Curiously, these appear at a rate of about one per year:

2012-13: One People's Public Trust (OPPT) ${ }^{104}$ — Promoters claimed that US Uniform Commercial Code filings had "foreclosed" governments, corporations, and banks. Subscribers were each promised $\$ 10$ billion in gold and payment of debts by "Courtesy Notice" documents. ${ }^{105}$ When the gold was not delivered OPPT promoters claimed it was held by aliens. The OPPT's core personnel then relocated to Morocco to develop free energy technologies.

2013-14: Gold Shield Alliance (GSA) ${ }^{106}$ — US-based GSA promised customers GSA would "zero" debts via A4V payments from a "birth trust account" operated by the US Treasury Department. Alberta Treasury Branches v. Nielson ${ }^{107}$ describes and rebuts the GSA scheme, whose details and mechanism were concealed from subscribers. ${ }^{108}$

Fielding and Platt, Ltd v Najjar, [1969] 2 All ER 150 at 152 (UK CA (Civ Div)).

See e.g. Child Maintenance and Enforcement Commission v Wilson, [2013] CSIH 95 at para 5 (Scot) [Wilson].

See e.g. Boisjoli, supra note 9 at paras 27-44; Potvin, supra note 20 at paras 33-34.

See e.g. Canadian Imperial Bank of Commerce v McDougald, 2017 ABQB 124 at paras 30-58 $[$ McDougald $]$.

See e.g. promissory notes that have "incorporated powerful sacred geometry," ibid at paras 30, 56 . Supra note 96.

Boisjoli, supra note 9 at paras 32-34; Parlee, supra note 9 at paras 65-68; McDougald, supra note 98 at paras 35-37; Wallace Maxwell Raymond Dove and Legal Aid Ontario, 2018 ONSC 17 at paras 4, 8; Potvin, supra note 20 at para 99; Knutson, supra note 9 at para 70.

Boisjoli, ibid at para 35.

Charles Mackay, Memoirs of Extraordinary Popular Delusions and the Madness of Crowds (London: Robson, Levey, and Franklyn, 1852).

See online: <http://i-uv.com>; <https://web.archive.org/web/20130302034540/http://oppt-in.com/>.

See online: Scribd <https://www.scribd.com/doc/125445535/OPPT-Courtesy-Notice-InstructionsImage-Version-03p00-1>. Though this scheme appears to have had a significant number of Canadian subscribers, no reported judgment has been identified that responds to OPPT-based financial claims. The language used by child sex offender Jonathon Livingstone Seagull strongly implies that Seagull claimed OPPT theories placed him outside Canada's criminal law authority: $R v$ Seagull, 2013 BCSC 1811, aff'd 2015 BCCA 164.

See online: <www.gold-shield-alliance.com>.

Supra note 9.

Ibid at para 39; Netolitzky, “Attack," supra note 17 at 177-78, 183. 
2015: $\quad$ ACCP "Menard Card."

2015-16: The WeRe Bank ${ }^{109}$ — What purports to be a United Kingdom bank operated by "Peter of England" provided subscribers cheques that would allegedly pay large sums. The WeRe Bank, however, did not promise to transfer money, only "Re," "units of time and space," via its "SPIT" and "SWALLOW" procedures. This scam, which is detailed in Servus Credit Union Ltd. v. Parlee, ${ }^{110}$ relies on "promissory notes are cash" pseudolaw. Peter of England subsequently re-marketed his scheme to German and Austrian customers.

2016-17: Swissindo Trust ${ }^{111}$ — Indonesian Mr. Sino, "King of Kings,” promises \$6 million US payments and monthly stipends drawn from the collective precious metal reserves of the world's royal families. Subscribers may (allegedly) discharge debts with colourful Debt Burden Liberation Certificates. $^{112}$

2017-18: OPPT Federal Reserve Bank Transfers - Former Washington State prosecutor and OPPT guru Heather Ann Tucci-Jarraf resurfaced with a scheme to defraud financial institutions via electronic funds transfers from Federal Reserve Bank accounts. Tucci-Jarraf was shortly thereafter arrested, convicted of bank fraud charges, ${ }^{113}$ and received a four-year nine-month prison sentence. ${ }^{114}$ Nevertheless, many donated funds to Tucci-Jarraf and have attempted to emulate this methodology.

See online: $<$ https://web.archive.org/web/20151003071322/http://werebank.com:80/> (original website); $<$ https://www.werebank.co.uk> (current website).

$110 \quad$ Supra note 9.

111 See online: Swissindo World Trust International Orbit $<$ swissindo.news $>$. Swissindo has spawned a number of regional spinoffs, online: <https://web.archive.org/web/20171229072801/http://www. americanswissindo.com/> (US); Facebook $<$ https://www.facebook.com/SWISSINDO-CANADA-1207," 282609297521/> (Canada). Arzia Tivany Wargadiredja, "The Debt Cult That Wants to Save the World," VICE (8 February 2018), online: <https://www.vice.com/en_asia/article/xw5x8z/the-debt-cult-thatwants-to-save-the-world-with-a-mountain-of-gold > provides additional background on the Swissindo phenomenon.

112 See online: Swissindo World Trust International Orbit < swissindo.news/wp-content/uploads/2016/04/ 301449733-WORLD-DEBT-BURDEN-LIBERATION-CERTIFICATE-4-3-2016-ENGLISH.pdf>. Zeleny v Canada, 2016 ONSC 7226, aff’d 2017 ONCA 745 involves Swissindo concepts. The plaintiff in this action, Deryl Clayton Zeleny, at one point purported that Mr. Sino had made him a Lieutenant General in command of Swissindo-aligned military forces, online: Global Fact Radio <www.blogtalk radio.com/globalfactradio/2013/09/20/conscious-living-guest-deryl-zeleny-and-swissindo-trust>.

113 US v Beane, 3:17-CR-82-TAV-CCS (ED Tenn 2017); United States Department of Justice, News Release, "Federal Jury Convicts Knoxville Man and Former Washington State Prosecutor Turned Leader of Sovereign Citizen Movement of Wire Fraud and Conspiracy to Commit Money Laundering" (1 February 2018), online: United States Department of Justice <https://www.justice.gov/usaoedtn/pr/federal-jury-convicts-knoxville-man-and-former-washington-state-prosecutor-turned $>$.

Travis Dorman, "Well-Known 'Sovereign Citizen' Sentenced in Federal Bank Fraud Case in Knoxville," Knoxville News Sentinel (17 July 2018), online: <https://www.knoxnews.com/story/news/crime/2018/ 07/17/heather-ann-tucci-jarraf-sovereign-citizen-hatj-sentenced-federal-bank-fraud-case/793925002/>. 
2018: Dean Clifford Debt Abatement - Canadian Freeman guru Dean Clifford and his numbered company, "Secured Party Lienors," accept "Strawman" birth certificate "Life Estates" and on behalf of Clifford's customers purport to discharge debts with A4V "abatement" and an ounce of silver as payment. ${ }^{115}$

The majority of these "get rich quick" schemes are either readily disposed of by Meads or its successor cases that address economic pseudolaw, or simply are obviously absurd.

\section{B. Meads' Unusual Continuing RELEVANCE AND EFFICACY}

Despite Meads' shortcomings, the decision remains highly effective to the present as a tool to recognize, understand, and rebut pseudolaw. In fact, the ongoing value of Meads is quite unexpected. An objective observer would plausibly anticipate a progression of measures and countermeasures. One might expect that OPCA theorists would review Meads, and then develop new ideas or mechanisms to work around the law collected in that decision. Logically, that would lead to an evolutionary contest of pseudolaw versus rebuttal, a Red Queen scenario ${ }^{116}$ of competing waves of real and illusionary law and legal theory.

That has not happened. As previously indicated, the modest degree of innovation to date is largely limited to new variations on "money for nothing" schemes.

Instead, pseudolaw has been stagnant. Three key motifs continue to dominate OPCA theory: (1) everything is a contract; (2) silence means consent; and (3) the "Strawman" legal versus physical person duality. ${ }^{117}$ While these ideas are to some degree reframed and reassorted, ${ }^{118}$ there has been no substantial evolution of these concepts. The "Strawman," in particular, has mesmerized the OPCA community, and not only in Canada, ${ }^{119}$ but in other countries and communities where Canadian Freeman pseudolaw has been transplanted, including Australia, ${ }^{120}$ New Zealand, ${ }^{121}$ the Republic of Ireland, ${ }^{122}$ the UK, ${ }^{123}$ South Africa, ${ }^{124}$

Landry, supra note 22. Clifford has been declared a vexatious litigant and made subject to strict court access restrictions as a result of him employing this scheme in Alberta.

The Red Queen hypothesis is an evolutionary biology concept that competing organisms, pathogens, and hosts engage in a continual evolutionary arms race of adaptation and counter-adaptation. See Leigh Van Valen, “A New Evolutionary Law" (1973) 1 Evolutionary Theory 1.

Meads, supra note 1 at Parts VI(B), VI(D), and VI(C), respectively.

Master Schulz in Pomerleau, supra note 9 at para 155, describes arguments in that decision as "clearly composed of old OPCA motifs, somewhat rearranged and rejiggered."

Netolitzky, "History," supra note 3 at 633-35.

See e.g. Australian Competition \& Consumer Commission v Rana, [2008] FCA 374; Christie v Commissioner of Police, [2014] QDC 70; Anderson v Kerslake, [2013] QDC 262. See also online: $<$ www.rightsandwrong.com.au>; Mark Pytellek, Weekend Workshop Manual (27-28 March 2009) at $152-58$.

See e.g. Hill v Māori Trustee, [2016] NZHC 364, leave to appeal refused, [2016] NZHC 1072 [Hill]; Meenken v Family Court at Masterton, [2017] NZHC 2103 [Meenken].

See e.g. Tír na Saor, Freeman Guide (Tír Na Saor, undated) at 20-23.

See e.g. Veronica: of the Chapman Family, Freedom Is More Than Just a Seven-Letter Word, 2nd ed (TamaRe House, 2010) at 162-77; infomaticfilms, "Meet Your Strawman!" (14 June 2010), online: YouTube <https://www.youtube.com/watch?v=ME7K6P7hlko> (a UK cartoon styled like a 1950s education film that introduces basic "Strawman" theory); The Nature of the Cage, "Strawman — The Nature of the Cage (OFFICIAL)" (30 July 2015), online: YouTube <https://www.youtube.com/ watch? $=7 \mathrm{sArXw6ajNg}>$ (interviews with UK Freeman figures that explain "Strawman" theories).

Brother Thomas, The Giftoftruth: South African Guide to Sovereignty and Commerce, 1st ed (July 2013). This document is a collage from various sources. 
and Norway. ${ }^{125}$ Emergent Canadian gurus such as "John Spirit," "26 Wally Dove, ${ }^{127}$ "Kate of Gaia," " and "Marcus" 129 advance variations on the "Strawman" motif.

The post-2012 application of Meads actually illustrates this lack of innovation. Meads is commonly described as a legal rebuttal of the then burgeoning Freeman-on-the-Land phenomenon. In fact, it is not. Meads collects nearly 150 OPCA-related decisions and summarizes information from those resources. However, a little appreciated aspect of Meads is that the large majority of the jurisprudence mined to prepare Meads does not, in fact, respond to the Freemen and their ideas. Only 6.7 percent $(n=10)$ of the reported OPCArelated cases cited in Meads exhibit a clear Freeman affiliation. ${ }^{130}$ Instead, the majority (57 percent, $\mathrm{n}=85$ ) of the court decisions relied upon in Meads used as sources to describe and illustrate pseudolaw involved litigants from the Detaxer movement.

Thus, Meads principally relied on OPCA theories from one OPCA movement (Detaxers), but that proved to be no handicap for courts which then applied the Meads schema to rebut pseudolaw from a socially distinct OPCA movement (Freemen). This pattern is not limited to Canada and these two separate OPCA communities. Meads has proven equally relevant and applicable in many other jurisdictions and pseudolaw contexts.

The over 20-year OPCA history of Dale Jacobi is a striking illustration of this fact. Jacobi, a former Calgary Police Service officer, was a leader of the Montana Freeman prototype Sovereign Citizen community. Jacobi was sentenced to nearly 14 years' incarceration following a several month armed standoff in 1996 between the Montana Freemen and the

Only an incomplete archived website remains of the apparent dominant personality in the Norwegian Freeman-on-the-Land movement, Ingunn Røiseland (online: <web.archive.org/ web/20130308073105/ http://www.freeman.no/>). This website and contemporaneous reporting indicates Røiseland was teaching Canadian "Strawman" theories: Dan Hagen, "Meldte seg ut av Norge," TA (16 November 2012), online: <www.ta.no/grenland/meldte-seg-ut-av-norge/s/1-111-6344863>; Asbjørn Dyrendal, "Norwegian "Conspirituality” A Brief Sketch" in James R Lewis \& Inga Bårdsen Tollefsen, eds, Handbook of Nordic New Religions (Leiden: Brill, 2015) 268 at 268. As of the date this article was prepared, the Norwegian Freemen appear to have gone extinct.

A pseudonym; his actual name is not known, online: The Place To Think It Through <eternally aware.com>; Using Our Intrinsic Rights <intrinsicfreedoms.com>; Enforcing Natural Rights and Freedoms Intrinsic Rights <johnspirit.education>; YouTube $<$ https:/www.youtube.com/channel/ UCk3Q6CI3GBHBpMWy3j1NpiQ>. Spirit in 2014-2016 devised a methodology where allegedly binding international treaties remove one's status as a legal person (the "Strawman"). Spirit offers various information packages that range in price between $\$ 250$ to $\$ 3,000$, online: The Place To Think It Through $<$ www.eternallyaware.com/information-store.html $>$. Arguments obviously derived from Spirit's websites and videos were dissected and rejected in Pomerleau, supra note 9.

Dove advanced a variation on Spirit's concept which was rejected in Federal Court: Dove v R, 2015 FC 1126, aff'd 2015 FC 1307, aff'd 2016 FCA 231 [Dove FCA], leave to appeal to SCC refused, 37487 (1 June 2017). See also Bouchard v R, 2016 FC 983; Claeys $v R, 2013$ MBQB 313; Doell v R, 2016 FCA 235; Holmes v R, 2016 FC 918 [Holmes]; O'Brien v Murchland, 2013 ONSC 4576; Pearce v R, 2016 FC 475.

128 "Kate of Gaia," legally named Keith Thompson, is a former Canadian Freeman-on-the-Land turned UK OPCA guru. Thompson's variation on "Strawman" theory centers on a claim that the Crown holds copyright in a legal name: see Netolitzky, "Magic," supra note 44 at 1083 . This concept was rejected in $R v$ Unger, 2016 ABPC 46.

Also known as Wilfred John Emonts: Netolitzky, "Family," supra note 2 at 970, n 98; Netolitzky, "Magic," supra note 44 at 1078; online: <www.servantking.info>.

130 Harperv Atchison, 2011 SKQB 38 [Harper]; Jabez Financial Services Inc v Sponagle, 2008 NSSC 112; $R v A N B, 2012$ ABQB 556 [ANB]; Rv Kaasgaard, 2011 MBQB 256; $R v$ McCormick, 2012 NSSC 150, bail denied 2012 NSCA 58; Sydorenko v R, 2012 MBQB 42; Szoo'v RCMP, 2011 BCSC 696 [Szoo']; United States of America v Emery, 2005 BCSC 1192. This low proportion of Freeman jurisprudence does not appear to be the result of a sampling error or bias. An additional 384 pre-19 September 2012 OPCA-related reported decisions were identified after Meads' publication. Only 6.0 percent $(\mathrm{n}=23)$ show a clear Freeman-on-the-Land affiliation. 
Federal Bureau of Investigation. ${ }^{131}$ After his release Jacobi was deported to Canada, where he continued to engage in illegal acts that he excused on a pseudolegal basis. Jacobi in a 2016 trial advanced "doctrines embraced by Freemen on the Land," which was "folly." 132 On appeal Jacobi complained he was no Freeman-on-the-Land. ${ }^{133}$ The trial proceeding was therefore allegedly unfair. In one sense, Jacobi is absolutely correct. His personal, social, and political beliefs in no way align with the Canadian Freeman community, aside from a shared rejection of and disdain for government authority. However, when it came to pseudolegal theory, there was no substantial difference between the Montana Freemen and the Freemenon-the-Land. Jacobi's complaint was irrelevant. ${ }^{134}$

In a way, Meads benefited greatly from a coincidence of timing and circumstance. The modus operandi of the Detaxers and Freemen-on-the-Land are very different. The former often engaged in careful analysis and extensive research. Detaxers (sometimes) presented their concepts in a clear, legally organized, though skewed, manner. Courts responded with thorough analytical responses in written decisions.

Stereotypic Freeman court appearances are instead highly ritualistic. Freeman documentary materials often approach incoherence. An example of this dichotomy is how Detaxer Russell Porisky, the founder of the Paradigm Education Group, engaged in a dialogue and exploration of "Strawman" theory during his first trial. ${ }^{135}$ In contrast, Freemanon-the-Land court appearances often dissolve into little more than nonsense where the Court and Freeman talk past one another. ${ }^{136}$ Detaxers pursued appeals, a practice that is rare in Freeman litigation.

The Detaxers' litigation heritage thus gave Meads a solid theoretical and analytical anchor. That was crucial if Meads was to explain and refute Canadian pseudolegal theories.

The remarkable lack of post-2012 pseudolegal innovation is difficult to explain. One hypothesis is that inventing pseudolaw is hard. The issue with this theory is that while some pseudolaw movements, such as the Sovereign Citizens and the Canadian Detaxers, built their theories from a historical and documentary foundation, other OPCA movements, like the Freemen-on-the-Land, simply make things up. ${ }^{137}$ Strangely, that does not appear to affect the marketplace viability of the latter approach.

A second alternative explanation is that pseudolaw achieves a better hold on potential host populations when it exists as a broad replacement scheme of law — an alternative system of law — rather than a few isolated "loophole" motifs that allegedly provide some advantage.

See e.g. Perreal v Knibb, 2014 ABQB 15 at paras 28-34 [Knibb]; Catherine Wessinger, How the Millennium Comes Violently: From Jonestown to Heaven's Gate (New York: Seven Bridges Press, 2000) at 158-203; J Patrick Shannan, The Montana Freemen: The Untold Story of Government Suppression and the News Media Cover-Up (Jackson: Center for Historical Analysis, 1996). Shannan's text provides a uniquely detailed review of Montana Freemen pseudolaw concepts.

$R v$ Jacobi, 2016 BCPC 121 at para 20, aff'd 2017 BCSC 1106.

$R v$ Jacobi, 2017 BCSC 1106.

Vibert $v A G$, [2013] JRC 030, addresses the same issue.

$R v$ Porisky \& Gould, 2012 BCSC 67 at paras 59-68 [Porisky], retrial ordered $R v$ Gould, 2014 BCCA 146 [Gould].

136 Rv Grant, 2016 ONCJ 170, is a sadly absurd but representative example.

137 Netolitzky, "Magic," supra note 44 at 1075. 
If so, then the challenge is to accumulate a threshold of interconnected and mutually supporting pseudolegal concepts, history, and literature. Once a minimum viable set of these ideas is achieved, then this "memeplex"138 of pseudolaw can potentially thrive when coupled with a corresponding anti-government narrative, particularly a conspiratorial one where there are two legal or government systems: a false and abusive facsimile law imposed by a tyrannical state and allied conspirators versus a true but hidden and suppressed law that provides for attractive but unorthodox personal freedoms. US legal scholar Susan P. Koniak argues the Sovereign Citizen world did exactly that and built its own distinct and separate schema of law. ${ }^{139}$

The international spread of pseudolaw suggests this second explanation is correct. ${ }^{140}$ The majority of modern pseudolaw was first invented and deployed by the US Sovereign Citizen movement and its predecessors. ${ }^{141}$ Then, starting around 2000, this concept set was transmitted to and adopted as a memeplex by other communities: in Canada via the Eldon Warman school of Detaxing ${ }^{142}$ and then Menard's Freemen-on-the-Land, ${ }^{143}$ and in the US to urban black separatist Moorish Law populations. ${ }^{144}$ The same memeplex of pseudolaw then spread in the late 2000s from Canada to the UK and other Commonwealth Freeman populations, ${ }^{145}$ and to the German language right-wing Reichsbürger community ${ }^{146}$ and other European groups. ${ }^{147}$

This latter alternative does not necessarily explain why certain pseudolaw motifs have persisted while other equally ineffective concepts have died off. One possibility is that the appeal of any given concept, such as the "Strawman," derives less from its logic or historical foundation (in both cases, limited) than other ceremonial characteristics. ${ }^{148}$ This question is better suited to a social sciences investigation.

This term originates from "meme theory," a method to explore how discrete ideas, "memes," exist, compete, spread, and disappear in a manner analogous to how genes operate in a biological context. See Richard Dawkins, The Selfish Gene (Oxford: Oxford University Press, 1976). A "memeplex" is a group of memes that have co-evolved and offer mutual support. See also Netolitzky, "Family," supra note 2 at 994-97; Netolitzky, "Rebellion," supra note 2, for discussion in an OPCA context. Susan P Koniak, "When Law Risks Madness" (1996) 8:1 Cardozo Stud L \& Lit 65 at 87-89, 106. See also Netolitzky, "Rebellion," ibid. Donald J Netolitzky, "A Pathogen Astride the Minds of Men: The Epidemiological History of Pseudolaw" (Paper delivered at the CEFIR Symposium "Sovereign Citizens in Canada," 3 May 2018) [unpublished], online: researchgate <www.researchgate.net/publication/325053635_A_Pathogen Astride the_Minds_of_Men_The_Epidemiological_History_of_Pseudolaw $>$ [Netolitzky, "Pathogen"] Ibid at $\overline{3}-4$

Netolitzky, "History," supra note 3 at 617-18; Netolitzky, "Pathogen," ibid at 6-8. Warman died in 2017, online: <www.vikingfuneralservices.ca/fh/obituaries/obituary.cfm?o_id=4244441\&>. Netolitzky, "History," ibid at 624-26; Netolitzky, "Pathogen," ibid at 9-10.

Netolitzky, "Pathogen," ibid at 4-5.

Ibid at 10-17. Australia and New Zealand are unusual in that they received pseudolaw from both the US and Canada, and have a rich history of locally-developed concepts.

Ibid at 14-15. The Reichsbürgers operate in both Germany and Austria. The typically right-wing Reichsbürgers combine the US Sovereign Citizen memeplex with pseudolaw that the modern German Federal Republic is invalid and illegitimate. The exact source of their US Sovereign-style OPCA motifs is not clear, though the OPPT is clearly implicated. See Jan Rathje, Die Reichsbürger: Überzeugungen, Gefahren und Handlungsstrategien (Berlin: Amadeu Antonio Stiftung, 2014); Dirk Wilking, "Reichsbürger": Ein Handbuch (Potsdam: Brandenburgische Universitätsdruckerei und Verlagsgesellschaft Potsdam mbH, 2015); FG Münster No 14 (14 April 2015), Az. 1 K 3123/14 F, online: <https://openjur.de/u/853611.html>. 
What is clear is that, to date, Meads remains a generally accurate and complete response to the dominant form of pseudolaw in Canada and worldwide. How long that will remain the case is uncertain, but plausibly this will continue until a new, independent, and unrelated matrix of pseudolaw and supporting materials appears to compete with both the mainstream "conventional" law in Canada and other countries, and the Sovereign Citizen-derived pseudolaw memeplex.

\section{RESPONSES TO MEADS}

Meads was immediately recognized as an important authority upon its release. This decision identified "a pervasive problem ... the elephant in the courtroom and called it for what it is." 149 UK commentators concluded Meads had "done many judges around the world a huge favour by exploding the movement's ideas and leaders." 150

\section{A. JURISPRUDENCE}

Meads has been broadly identified as a critical resource to understand and respond to pseudolaw. In Canada, Meads has been cited in 198 reported court and tribunal decisions, and endorsed by five Canadian Courts of Appeal. ${ }^{151}$ CanLII indicates Meads is the most cited post-2012 decision issued by the Alberta Court of Queen's Bench. ${ }^{152}$

As the OPCA phenomenon spread worldwide, Meads followed. Meads is broadly accepted throughout the Commonwealth: in the UK, Australia, Jersey, the Republic of Ireland, New Zealand, Northern Ireland, and Scotland. ${ }^{153}$ A recent Austrian Federal Court decision which involved the European Reichsbürger phenomenon ${ }^{154}$ identifies Meads as "instructive" for the general characteristics of pseudolaw arguments and movements. ${ }^{155}$

Margaret L Waddell, "Finally, Some Plain Talk About a Pervasive Problem," Canadian Lawyer Mag (8 October 2012), online: <https://www.canadianlawyermag.com/author/margaret-l-waddell/finallysome-plain-talk-about-a-pervasive-problem-1791/>.

Adam Wagner, "Freemen on the Land Are 'Parasites' Peddling 'Pseudolegal Nonsense"': Canadian Judge Fights Back" (30 September 2012), UK Human Rights Blog (blog), online: <https://ukhuman rightsblog.com/2012/09/30/freemen-of-the-land-are-parasites-peddling-pseudolegal-nonsense-canadianjudge-fights-back $>$.

$R v$ Blerot, 2015 SKCA 69 at para 4; d'Abadie \#1, supra note 40; Minicozzi c Royal Bank of Canada, 2013 QCCA 1722 at para 2; Nadeau c Autorité des marchés financiers, 2018 QCCA 1913 at para 1; Fiander v Mills, 2015 NLCA 31 at paras 11, 19, 38 [Fiander]; Bossé, supra note 9; Tupper v Nova Scotia (Attorney General), 2015 NSCA 92 at para 53, leave to appeal to SCC refused, 36761 (10 March 2016) [Tupper].

See online: CanLII <https://www.canlii.org/en/\#search/sort=citationCount\&id=abqb>.

153 Crossroads, supra note 70 at para 45; Hill, supra note 121; Meenken, supra note 121; Foster $v$ McPeake, [2015] NIMaster 14; Ulster Bank Limited v DACE Properties Limited, [2017] NICh 10; Adelaide City Council v LEPSE, [2016] SASC 66 [LEPSE]; Hewitt v Corbett, [2016] FCCA 776 [Hewitt]; Coshott v Spencer, [2016] NSWDC 43 [Coshott]; Ennis, supra note 70; Deputy Commissioner of Taxation $v$ Woods, [2018] FCCA 1815 [Woods]; Lion, supra note 70; CH v SSWP (JSA) (No 2), [2018] UKUT 320 (Upper Tribunal, Administrative Appeals Chamber). 
This, in turn, has led to a kind of "international dialogue." Foreign courts rely on Meads, ${ }^{156}$ then courts in Canada use that jurisprudence to counter abusive OPCA concepts. ${ }^{157}$

Meads is recognized for its scope and detail. It is "a textbook of abusive OPCA practices," 158 a "very thorough and thoughtful decision," "159 "a comprehensive analysis of this phenomenon," "160 and "[t] he seminal case on matters of this kind." ${ }^{161}$ Collecting and capturing this information saves trial courts from "reinventing the wheel":

Justice Rooke dealt with these matters exhaustively in Meads ... in part so judges in future would be spared that burden and so that these litigants would not succeed in their apparent aim of bogging down the justice system with nonsensical arguments which would have to be dealt with piecemeal by each and every judge they appear before. ${ }^{162}$

Justice O'Donnell's colourful response to the release of Meads bordered on exuberant. As such, 18 September 2012 was called "a day that will shine in virtue" as "the gods made their benevolent nature clear" by providing a "comprehensive judgment" "disentangling $\mathrm{Mr}$. Duncan's adopted argument and his volume of internet-derived gibberish."163

Australian court decisions illustrate how Meads serves multiple roles. Meads identifies and rebuts pseudolaw, ${ }^{164}$ describes the host communities for these ideas, ${ }^{165}$ illustrates how to manage litigation of this kind, ${ }^{166}$ but also reviews general legal principles. ${ }^{167}$

Meads proposed certain policies to help manage OPCA litigation. ${ }^{168}$ One is that the courts take steps to identify and terminate OPCA arguments, for example by "show cause" procedures or court filing restrictions, like those applied to Gauthier. ${ }^{169}$ The Newfoundland Court of Appeal in Fiander v. Mills made that a point of law: several cornerstone OPCA

Freeman v Bank of Scotland (Ireland) Limited, [2013] IEHC 371 at para 30; Kearney v KBC Bank Ireland Plc, [2014] IEHC 260 at paras 19-20; McCarthy $v$ Bank of Scotland Plc, [2014] IEHC 340 at paras 11-12; Harrold v Nua Mortgages Limited, [2015] IEHC 15.

Crossroads, supra note 70 at para 84; Rogozinsky, supra note 57 at paras 45-46.

Jarvis $v$ Morlog, 2016 ONSC 4476 at para 3 [Morlog].

Harms $v$ British Columbia (Attorney General), 2015 BCSC 1309 at para 26, aff'd 2016 BCCA 247. See also $R v$ Boxrud, 2014 SKQB 221 at para 22.

Tupper, supra note 151 at para 53. See also $R v$ Westover, 2013 ONCJ 472 at para 36.

$R v$ Lavin, 2013 ONCJ 6 at 9.

$R v$ Ainsworth, 2015 ONCJ 98 at para 6.

$R v$ Duncan, 2013 ONCJ 160 at paras 20-22 [Duncan]. See also $R v$ Freer, 2017 ONCJ 623 at para 4.

LEPSE, supra note 153 at para 57; Ennis, supra note 70 at para 17; Deputy Commissioner of Taxation $v$ Aitken, [2015] WADC 18 at para 40; Kosteska v Magistrate Manthey \& Anor, [2013] QCA 105 at paras 17-19; ACM Group Ltd v Jenner, [2014] QMC 7 at paras 23-27 [ACM Group]; Lion, supra note 70 at paras 20, 25; Woods, supra note 153 at para 9.

ACM Group, ibid at paras 23-24.

LEPSE, supra note 153 at paras 56-67; Hewitt, supra note 153 at para 78.

Coshott, supra note 153 at para 79.

Meads, supra note 1 at paras 628-41.

See text accompanying footnotes 43-47. 
concepts are a prima facie basis to shift the onus to a party to prove their litigation is valid. ${ }^{170}$ Ontario courts have applied Rule 2.1 in an analogous manner. ${ }^{171}$

A second Meads recommendation is that non-lawyer OPCA representatives are excluded. That too has been followed. ${ }^{172}$

This does not, however, mean that Meads has been applied in an automatic and indiscriminate manner. While to date Meads' analysis and rebuttal of pseudolaw has been adopted effectively in toto, there is a particular point on which recommended practices suggested in Meads have not been followed, even in the Alberta Court of Queen's Bench itself. Meads suggested as a general principle that deploying OPCA strategies should lead to elevated cost awards, and innocent parties who are abused by OPCA strategies should be indemnified. ${ }^{173}$ Though judges agree that OPCA concepts are by their nature abusive and vexatious, those ideas do not inevitably lead to elevated costs.

Some OPCA litigants are perceived as victims. For example, elevated costs were rejected even where an action was based on OPCA arguments which were "sheer and utter nonsense." " Justice Blok in Robert John: of the familymacmillan v. Johannson observed: "It is hard to know whether to condemn the proponents of these preposterous arguments or whether to sympathize with them for having been duped by others into believing them, but the result is the same." 175

Similarly, Master Schlosser in Servus Credit Union Ltd. v. Parlee declined to order costs, observing that after having lost their home despite multiple OPCA defences, "[t]he Parlees have lost enough already." 176 Good conduct, such as where the OPCA litigant "attempted to conduct himself in a cooperative and constructive manner" led to party-and-party costs. ${ }^{177}$

However, these outcomes are also an indirect consequence of Meads. Meads exposed the guru/customer structure of the OPCA phenomenon. That led to understanding and sympathy for these individuals as victims of a scam.

Fiander, supra note 151 at paras 40-49, adopted in Boisjoli, supra note 9 at para 16; Parlee, supra note 9 at para 84; Crossroads, supra note 70 at paras 40-41, 47; Cormier v Nova Scotia, 2015 NSSC 352 at para 32; Starr, supra note 40 at para 38; Greter, supra note 57 at para 28; Pomerleau, supra note 9 at paras 72-74; Re Gauthier, supra note 9 at paras 61-62; Rothweiler v Payette, 2018 ABQB 134 [Rothweiler \#2]; d'Abadie \#2, supra note 42 at paras 67-69; Leadbetter, supra note 45 at paras 19-20; Hawrysh \#1, supra note 45 at paras 27-28; McKechnie (Re), 2018 ABQB 493 at paras 23-24; Potvin, supra note 20 at paras 68-92; Landry, supra note 22 at paras 20-21; Knutson, supra note 9 at paras 49-55. Rothweiler \#3, supra note 65, expands this approach to the Three/Five Letters scheme.

Ontario, Rules of Civil Procedure, RRO 1990, Reg 194, r 2.1. See Gao v Ontario WSIB, 2014 ONSC 6100; Gao v Ontario WSIB, 2014 ONSC 6497; Scaduto v The Law Society of Upper Canada, 2015 ONCA 733, leave to appeal to SCC refused, 36753 (21 April 2016); Brent Kettles, "Staying and Dismissing Frivolous, Vexatious and Abusive Proceedings: Ontario Rule 2.1" (2016) 46:1 Adv Q 124. The Law Society of British Columbia v Crischuk, 2017 BCSC 531 [Crischuk]; Knibb, supra note 131 at para 36; Starr, supra note 40 at paras 54-56; The Law Society of British Columbia v Boyer, 2016 BCSC 342 at para 38, interim injunction denied, 2016 BCCA 169 at para 18; Landry, supra note 22 at para 57.

$173 \quad$ Meads, supra note 1 at para 631

174 Robert John: of the familymacmillan v Johannson, 2017 BCSC 1069 at para 10.

175 Ibid.

$176 \quad$ Parlee, supra note 9 at para 84.

177 Pomerleau, supra note 9 at paras 150-53. 
Elevated cost awards do occur. Evidence of bad intention appears to be a relevant factor. For example, OPCA debt elimination strategies warrant indemnity costs where the OPCA litigant was warned those concepts were invalid. ${ }^{178}$ In Bossé, the New Brunswick Court of Appeal awarded indemnity costs after concluding an A4V scheme defied logic, and the OPCA litigants knew it. ${ }^{179}$ Another apparent distinction is where the OPCA litigant attacks the other party, seeking money or penalties. That favours elevated cost awards ${ }^{180}$ and vexatious litigant status. ${ }^{181}$

\section{Lump sum awards are also commonplace. ${ }^{182}$}

In conclusion, Meads' influence on Canadian and Commonwealth jurisprudence is apparent in two senses. One is obvious: Meads is a commonplace legal tool, frequently applied and cited, but without much additional comment. That illustrates how, in the broadest sense, this decision has proven effective.

The second plausible effect of Meads is more subtle. When one compares US versus Commonwealth OPCA jurisprudence, the latter tends to provide more detailed and specific replies to pseudolegal arguments. Meads is an archetype of that approach, but, as previously explained, these "full responses" are not unique to Meads, but instead are an extension of the pre-2012 case law Meads itself summarized. In that sense, Meads continues the Canadian approach to this form of abusive litigation, but in a comprehensive manner.

\section{B. ACADEMIC}

Meads is not just a tool for judges and lawyers. This decision has also become a key reference for academics, though not legal academics.

In Canada, legal academia has paid essentially no attention to pseudolaw, both before and after Meads. The only refereed Canadian paper from a legal academic source that comments at any length on Meads offers little more than a superficial review of the decision's subject matter. $^{183}$

McDougald, supra note 98 at para 61; Canadian Imperial Bank of Commerce v Hartloff, 2016 SKQB 155 at para 35 [Hartloff]; Bank of Nova Scotia v Radoux, 2018 SKQB 111 at para 34; Canadian Imperial Bank of Commerce v Radoux, 2018 SKQB 112 at paras 37-38.

Supra note 9 at para 42. See also Nielson, supra note 9 at paras 30-31; Greter, supra note 57 at para 33. See e.g. Morlog, supra note 158 at para 8; Little Shuswap Lake Indian Band v August-Sjodin, 2016 BCSC 1214 at paras 46-49; Myers v Blackman, 2014 ONSC 5226 at paras 35-36; Thompson Bey v Iyer, 2016 FC 990 at paras 9-10; Rogozinsky, supra note 57 at paras 92-93; Herbison v Canada (Attorney General), 2014 BCCA 461 at para 35; Gidda v Hirsch, 2014 BCSC 1286 at paras 86-89.

1985 Sawridge Trust v Alberta (Public Trustee), 2017 ABQB 548 at paras 68-74, subsequently applied in Rothweiler \#3, supra note 65 at paras 40-41; d'Abadie v Her Majesty the Queen, 2018 ABQB 438 at paras 5-7; Alberta Treasury Branches v Hawrysh, 2018 ABQB 618 at para 29; McKechnie (Re), 2018 ABQB 677 at paras 33-34; Potvin (Re), 2018 ABQB 834 at paras 12-14; Landry, supra note 22 at paras 35-36.

See e.g. Blackshear v R, 2013 FC 590 at para 15; Dove FCA, supra note 127 at para 6; ANB v Hancock, 2013 ABQB 97 at paras 100-106.

Amy Salyzyn, "Canada: Foreclosures, Freemen, Foreign Law Schools and the Continuing Search for Meaningful Access to Justice" (2013) 16:1 Leg Ethics 223. Interestingly, Slovak law professor Martin Turčan appears to have used Meads as a basis to examine theories of social contract and state authority: M Turčan, "Pseudoprávo" (2016) 99:2 právny obzor 138, online: <www.pravnyobzor.sk/index.php? $\mathrm{id}=$ po22016 $>$ (English-language abstract). 
This lack of interest is somewhat peculiar, especially given how the OPCA phenomenon and Meads have attracted significant public and professional attention. Arguably, this apparent disinterest is a lack of opportunity. OPCA litigation is often an emergent and transient phenomenon. An OPCA litigant appears with little warning and makes peculiar and cryptic submissions, which are then dismissed. These encounters are often during preliminary, interlocutory, or summary proceedings. That explanation ignores that OPCA litigation leaves a rich paper trail. Court files filled with OPCA documents and argument are readily accessible.

Another explanation is that academics may perceive pseudolaw as not really a relevant or appropriate area of study. It is "not law," and only gibberish and foolishness. That said, legal academics do identify Meads as the type study which defines and documents the pseudolaw phenomenon. $^{184}$

The one exception is where legal academics have blogged about the OPCA phenomenon and focused on a potential interrelationship between OPCA litigation and the broad-based appearance of self-represented litigants (SRLs) in Canadian courts. This involved two questions, whether: (1) some OPCA litigants are naive SRLs who have innocently adopted pseudolaw, not realizing these concepts were suspect, ${ }^{185}$ and (2) judges are unable or unwilling to distinguish between "fair dealing" SRLs versus abusive and malicious OPCA litigants. $^{186}$

Both questions betray that the writers have a blind spot. They had not investigated the host populations that use pseudolaw, and instead were guessing at the characteristics of OPCA litigants. The succinct answer to the first question is that pseudolaw is marketed or presented in an unprofessional and conspiratorial manner. A reasonable novice layperson should find these sources questionable. ${ }^{187}$ Some SRLs do, nevertheless, ignore those warning signs, for example, out of greed. ${ }^{188}$

The "conflation" question means splitting SRLs into "legitimate" versus "illegitimate" subtypes. The former deserves special treatment, ${ }^{189}$ while the latter are "vexatious" and subject to control. This distinction is artificial. Some persons adopt but then abandon pseudolaw. ${ }^{190}$ A recent investigation discovered individuals who simultaneously engaged in

See e.g. Alice Woolley \& Trevor Farrow, "Addressing Access to Justice Through New Legal Service Providers: Opportunities and Challenges" (2015-2016) 3:3 Texas A\&M L Rev 549; Hamish Stewart, "The Wrong of Mass Punishment" (2018) 12:1 Criminal L \& Philosophy 45, online: <https://link. springer.com/content/pdf/10.1007\%2Fs11572-016-9409-2.pdf>; Narelle Bedford \& Monica Taylor, "Model No More: Querulent Behaviour, Vexatious Litigants and the Vexatious Proceedings Act 2005 (Qld)" (2014) 24 J Judicial Administration 46; Daphna Hacker, "Divorced Israeli Men's Abuse of Transnational Human Rights Law" (2016) 28:1 CJWL 91; NW Barber \& Adrian Vermeule, "The Exceptional Role of Courts in the Constitutional Order" (2016) 92:2 Notre Dame L Rev 817.

Netolitzky, "Attack," supra note 17 at 140-43, 191-92.

Netolitzky, "Family," supra note 2 at 957, 994.

Netolitzky, "Attack," supra note 17 at 140-43, 176-79, 191-92.

See e.g. Fiscal Arbitrators customers: Netolitzky, "Lawyers," supra note 33 at 430-34; Netolitzky, "Magic," supra note 44 at 1079.

Now formally acknowledged in Pintea $v$ Johns, 2017 SCC 23, which endorsed the Canadian Judicial Counsel, Statement of Principles on Self-Represented Litigants and Accused Persons (2006) that, among other things, mandates different procedural and evidentiary standards for SRL and represented litigants. Netolitzky, "Attack," supra note 17 at 179-81; Netolitzky, "Family," supra note 2 at 992-95; Netolitzky, "Lawyers," supra note 33 at 430-34. 
both OPCA and conventional litigation, despite holding anti-government beliefs. ${ }^{191}$ Social scientists who investigated pseudolaw populations found a diverse community with a range of motivations. ${ }^{192}$ All this illustrates how a review of only a few reported court cases is a problematic foundation to evaluate pseudolaw, its effects, and hosts. Instead, this is a social phenomenon. That is one reason courts are better positioned than many to comment on OPCA litigants. They see these people in action, first-hand, and in a variety of litigation contexts.

So do some lawyers. These legal practitioners have provided most of the investigation and commentary of the OPCA phenomenon in Canada, ${ }^{193}$ New Zealand, ${ }^{194}$ and the Republic of Ireland. ${ }^{195}$ Their publications consistently identify Meads as the keystone reference.

Reference literature also identifies Meads for both specific principles, such as that there is no such thing as common law copyright, ${ }^{196}$ and in broader contexts, such as vexatious litigation. ${ }^{197}$

Meads has become an interdisciplinary resource used by professionals in sociology, ${ }^{198}$ psychiatry, ${ }^{199}$ threat assessment,${ }^{200}$ communications,${ }^{201}$ and criminology ${ }^{202}$ to identify and describe pseudolaw concepts and communities.

Netolitzky, "Family," ibid at 967-71, 989-92, 994.

TSAS, "Broadening Our Understanding," supra note 15; Stephen A Kent, "Freemen, Sovereign Citizens, and the Challenge to Public Order in British Heritage Countries" (2015) 6 Intl J Cultic Studies 1.

Netolitzky, "Family," supra note 2; Netolitzky, "History," supra note 3; Netolitzky, "Attack," supra note 17; Netolitzky, "Magic," supra note 44; Netolitzky, "Lawyers," supra note 33; Jason K Yamashita, "Utility Dealings with Freemen-on-the-Land and Others Raising 'Organized Pseudo-Legal Commercial Arguments"' (2015) 3:2 Energy Regulation Q 51; Izaak de Rijcke, "A Strange Take on The Rule of Law: How Meads Raises Questions About Property Rights" (2012) 66:4 Geomatica 333.

Bloy, supra note 68.

Tomás Keys, "Freeman on the Land and Other Organised Lay Litigant Groups - Part 1" (2014) 10 Commercial L Practitioner 230; Tomás Keys, "Freeman on the Land and Other Organised Lay Litigant Groups - Part 2" (2014) 11 Commercial L Practitioner 256; Garret Sammon, “'Organised PseudoLegal Commercial Argument' Litigation: Challenges for the Administration of Justice in Ireland" (2015) 38:1 Dublin ULJ 85; Niamh Barry \& Macdara O Drisceoil, "Constitutional Right to Protest and the Freemen on the Land Movement" (2017) 1 Irish Judicial Studies J 40.

Hugues G Richard \& Laurent Carrière, eds, Canadian Copyright Act - Annotated (Toronto: Carswell, 1993), s 89; Barry B Sookman, Computer, Internet and Electronic Commerce Law (Toronto: Carswell, 1988), ch 3.1 .

Allan A Fradsham, Alberta Rules of Court Annotated 2017 (Toronto: Thomson Reuters, 2016), r 3.2; Brian J Saunders, The Honourable Mr. Justice Donald J Rennie \& Graham Garton, Federal Courts Practice 2017 (Toronto: Thomson Reuters, 2016), r 40; Garry D Watson \& Michael McGowan, Ontario Civil Practice 2017 (Toronto: Carswell, 2016), r 2.1; Richard McLaren, Secured Transactions in Personal Property in Canada, 3rd ed (Toronto: Carswell, 1989) at \$15.02[7].

Stephen A Kent \& Robin D Willey, "Sects, Cults, and the Attack on Jurisprudence" (2013) 14 Rutgers JL \& Religion 306; Kent, supra note 192; Dyrendal, supra note 125.

Pytyck \& Chaimowitz, supra note 48.

Angela W Eke et al, "Threats, Approach Behavior, and Violent Recidivism Among Offenders Who Harass Canadian Justice Officials" (2014) 1:3 J Threat Assessment \& Management 188.

Calum Lister Matheson, "Psychotic Discourse: The Rhetoric of the Sovereign Citizen Movement" (2018) 48:2 Rhetoric Society Q 187.

TSAS, "Broadening Our Understanding," supra note 15. 
The recent survey of the Freeman population by Barbara Perry, David Hofmann, and Ryan Scrivens highlights the key role Meads played in that study. Meads was "ground-breaking" and " $[\mathrm{t}]$ he most systematic analysis grounded in primary data to date." ${ }^{203}$ While that decision provided an important starting point scheme of community subgroups, ${ }^{204}$ Meads is a descriptive rather than analytical resource, and only shows the "outsiders" perspective of the OPCA phenomenon. ${ }^{205}$ This last observation is without question correct, and illustrates why social sciences investigation of communities that host pseudolaw is so important.

At the most basic level, Meads is about making courts work. This perhaps most critical role for Meads was identified by Kirsten Morry. ${ }^{206}$ Meads and its successor decisions ensure access to justice via a gatekeeper function: screening out abusive illegitimate litigation so that persons with real disputes can access the courts in a timely, cost-effective manner.

That gatekeeping can only occur where courts and other involved actors know about the existence, characteristics, and strategies of the abusive target population. Meaningful countermeasures are then possible. Meads, in that sense, laid a useful foundation, and some inside academia are now building off that.

\section{THE OPCA COMMUNities ResPond TO MEADS}

The OPCA communities remain largely silent about Meads six years later. That muteness is telling. There is little doubt the judgment is well-known, if not notorious. Courts urge OPCA litigants to read Meads because it responds to their arguments. ${ }^{207}$ That said, there is surprisingly little open discussion about Meads within the "OPCAsphere," the social space occupied by practitioners and advocates of pseudolaw. ${ }^{208}$ Instead, broaching the subject is considered bad manners. The fact that no reasoned response has emerged from the OPCAsphere to rebut Meads and other related jurisprudence seems to embarrass those dedicated to OPCA ideas and objectives.

The persons who market pseudolaw for profit, "OPCA gurus," offered little meaningful criticism or response. The first substantive rebuttal was, in many ways, the most surreal. Less than a month after Meads was released, Australian OPCA guru Frank O'Collins published a paper redefining "OPCA" to mean "Organized Pseudo-Lawful Commercial Architecture,"

Ibid at 7

Ibid at $24-44$

Ibid at 7-8.

Kirsten Morry, "Magna Carta and the Canadian Access to Justice Crisis" (28 November 2015), online: Magna Carta 2015 Canada <www.magnacartacanada.ca/magna-carta-and-the-canadian-access-tojustice-crisis/>.

See e.g. Duncan, supra note 163 at para 21; Pilot Butte (Town) v Gerein, 2015 SKPC 142 at para 25; Crischuk, supra note 172 at para 33; $R v$ White, 2017 BCPC 380 at para 6; Rothweiler v Payette, 2018 ABQB 108 at para 10; Landry, supra note 22 at para 63.

Netolitzky, "History," supra note 3 at 635-36; Netolitzky, "Family," supra note 2 at 961-63, 992-93. 
a complex of fraudulent laws purportedly developed by "the Roman Cult." ${ }^{209} \mathrm{O}$ 'Collins then encodes his rejection of "OPCA" in Canons 6870-75 of the "Astrum Iuris Divini Canonum":

Canon 6870

Organized Pseudo-Lawful Commercial Architecture (OPCA) is a universally recognized description and acronym to define a comprehensive commercial system of law, statutes, offices, administration, history, enforcement based on fraud, false presumptions and repudiation of time honored principles of Divine Law, Natural Law, Positive Law and Rule of Law. ${ }^{210}$

These "Canons" are an entirely unique, invented system of law, and a part of O'Collins' Ucadia project. Ucadia is amongst the most unusual and certainly most expansive expressions of pseudolegal culture, worldwide. Though now no longer publicly available, the original UCADIA website ${ }^{211}$ attempted to create a complete system of knowledge, social organization, government, finance, and law. As one observer explained, this massive and unique project is a "complete infrastructure of a world which doesn't exist, written largely by one man, with seemingly no one listening." 212

Rather than actually responding to Meads, O'Collins simply redefined the conflict and allegedly nullified that decision's effect. Though hard to believe, O'Collins' declaration is nevertheless relied upon by persons in pseudolaw communities. ${ }^{213}$

In February 2013, The Human Rights Defenders League in Canada released a more conventional rebuttal: "Meads v. Meads an Analysis." 114 The author, who is probably Wally Dove, identified Meads as a weapon that targets human freedoms: "There can be no question that this decision/opinion is an attempt by the BAR Association to vilify and demonize those human beings who simply claim to be human beings, and do so maliciously." 215

Writing "BAR" in capital letters indicates Dove subscribes to a conspiracy theory that lawyers, worldwide, are clandestinely organized under the "British Accredited Registry" or "British Accreditation Registry." 216 Dove continues to conclude Meads could not have been the product of a single judge, since "judges rarely ever write their own decisions"; Meads

Frank O'Collins, “OPCA Explained - Why a Most Recent Opinion by the Queen's Bench in Canada Exposes the Secret Bar Guilds as the Most Radical and Dangerous Anti-Social and Anti-Law Group in the World" (2 October 2012), Ucadia Blog (blog), online: <https://web.archive.org/web/20160330 173231/blog.ucadia.com/2012/10/opca-explained-why-most-recent-opinion.html $>$. Though the original Ucadia Blog version is no longer available, this rebuttal continues to circulate in OPCA communities, for example this video (mark seylon, "EVERYONE NEEDS TO KNOW THIS Meads v Meads" (1 April 2017), online: YouTube <https://www.youtube.com/watch? $=$ =nqG cVfY9i8>) uploaded by Mark "Ceylon" Laining, guru of the Get Out Of Debt Free website: Netolitzky, "History," supra note 3 at 631. O'Collins, ibid.

See archived version, online: <https://web.archive.org/web/20150315034602/http://ucadia.com/>.

"UCADIA: A Lost, Strange Civilization of the Internet" (10 May 2013), The Moral Animal (blog), online: <https://themoralanimal.wordpress.com/2013/05/10/ucadia-a-lost-strange-civilization-of-theinternet $>$.

See e.g. Letter from Allen-Nelson of the Boisjoli family to JD Rooke, Honourable Associate Chief Justice (5 November 2015), online: Scribd <https://www.scribd.com/document/2889 33562/Rebuttalfor-Rooke>.

214 The Human Rights Defenders League, "Meads v. Meads an Analysis" (3 February 2013), online: $<$ https://www.scribd.com/document/215311764/An-Analysis-of-Meads-v-Meads>.

Ibid at 1.

216 Netolitzky, "Lawyers," supra note 33 at 486. 
was a team project with a malevolent intent. ${ }^{217}$ Dove identifies a concealed subtext: whenever Meads uses the word "person," that term refers to the "Strawman" non-corporeal legal doppelganger illegitimately attached to human beings. ${ }^{218} \mathrm{He}$ concludes this means Meads is irrelevant to individuals who claim unorthodox and extraordinary rights under international treaties as "human beings." ${ }^{219}$ Dove and his followers subsequently argued that concept in court, but without success. ${ }^{220}$

The high profile Canadian OPCA gurus responded via their preferred medium: YouTube videos. Founder of the Freeman movement, Robert Menard, was particularly offended by being classified as a conman and guru. ${ }^{221}$ Interestingly, Menard admits that certain aspects of fee schedules and "Strawman" defences are illegitimate; however, he offers no actual legal or analytical response to Meads. Menard instead makes political allegations of state and court corruption, immorality, bias, and other wrongdoing. Menard restates the core principle of Freeman-on-the-Land ideology — Freemen-on-the-Land can choose what law does or does not apply to them. Paradoxically, Menard still claims Freemen do not consider themselves above the law.

Menard makes what he says are responses to the seven questions Associate Chief Justice Rooke in Meads proposed persons ask OPCA gurus, ${ }^{222}$ but Menard's answers are, at best, either evasive or bald allegations of conspiracy, court bias, and dishonesty. Menard says court misconduct, such as Meads, promotes and preserves corrupt business and government interests and "legal imaginary fictions." Menard concludes with a threat to form his own courts if he is unsatisfied with Associate Chief Justice Rooke's response to his video.

The one relatively substantial fact Menard does advance is that Freeman theories have been proven by an unnamed New Zealand court decision where persons were acquitted after they damaged a government facility. Closer examination reveals that claim is, to be generous, dubious. Menard was apparently referencing an acquittal of three protestors in 2008 who had attacked the New Zealand Waihopai Facility, a signals intercept station, and collapsed a radar dome. The protestors claimed this was lawful and justified as a "claim of right" against militarism, the war in Iraq, and US interests.

Menard, however, fails to recognize, or acknowledge, that this prosecution is essentially meaningless. First, the result was an acquittal by a jury, and therefore has no weight as precedent. Second, this was foreign litigation that relied on a provision in the New Zealand Crimes Act 1961, ${ }^{223}$ which has no Canadian equivalent. ${ }^{224}$ Third, and worse, the three protestors who had caused the damage were found liable in tort for $\$ 1.2$ million via summary

The Human Rights Defenders League, supra note 214 at 1, 10.

Reviewed in Netolitzky, "Magic," supra note 44 at 1069-78.

The Human Rights Defenders League, supra note 214 at 4-5, 10.

See footnote 127.

Mrmitee, "Justice Rooke Vs Freeman Menard: Court of Public Opinion - Canada" (5 October 2012), online: YouTube $<\mathrm{https}: / / \mathrm{www}$.youtube.com/watch? $\mathrm{v}=\mathrm{qFNiYHlk} 3 \mathrm{E}>$.

Meads, supra note 1 at para 668 .

Crimes Act 1961 (NZ), 1961/43.

Esther King, "Regulatory Impact Statement: Reform of the Claim of Right Defence" (18 October 2010), online: Ministry of Justice <https://www.justice.govt.nz/assets/Documents/Publications/RegulatoryImpact-Statement-Claim-of-Right.pdf $>$ provides a useful review of Commonwealth approaches to this concept. 
judgment. ${ }^{225}$ That result was subsequently confirmed by the New Zealand Court of Appeal, which concluded the defendants had no legal defence for their actions. ${ }^{226}$ New Zealand later amended the Crimes Act 1961 in response to the Waihopai Facility incident ${ }^{227}$ and limited the "claim of right" defence to personal property. That abolished the defence advanced by the Waihopai Station protestors.

Menard subsequently uploaded a "Video Portion of Complaint to the Judicial Council of Canada," 228 which alleged the Meads decision was unjustified, malicious, politically motivated; mischaracterized the Freeman phenomenon; and thus was defamation. Menard warned darkly that additional video will be released if he is killed. Unsurprisingly, Menard never actually made any complaint against Associate Chief Justice Rooke to the Canadian Judicial Council. ${ }^{229}$ This video was nothing more than online theatre.

"Muscular Freemanist" guru Dean Clifford ${ }^{230}$ announced he had not read Meads past page three. ${ }^{231}$ The rest was obviously nonsense. Clifford concluded Meads was a calculated product written by a team of lawyers, and intended to intimidate those who might otherwise use OPCA concepts. Judges are "supernumerary." That means they are only actors. The appearance of court decisions that report pseudolaw had failed meant the Freeman movement was clearly winning. Clifford explained reported decisions try to hide the fact Freemen are often successful. Clifford alleged that records and court files are concealed or destroyed to suppress that fact.

Edward Jay Robin Belanger, the guru and leading personality of the Church of the Ecumenical Redemption International, ${ }^{232}$ on 8 October 2012, posted a rambling but colourful stream of consciousness video response to $M e a d s .{ }^{233}$ Belanger espoused on his religion-based variant on "Strawman" theory: he rejects associating with a "legal fiction dead person" and "fictional law." Queen Elizabeth II's authority flows from her commitment to enforce Biblical law. Belanger explained "a man named Rooke" "masquerading as a judge" had written Meads to guarantee and protect his "superannuation person fund" (allegedly) collected from the court judgments Associate Chief Justice Rooke had authored. Banks and judges collect money from people much like how humans are used as batteries in the movie "The Matrix."

AG v Leason, [2011] NZHC 1053.

Leason v $A G$ [2013] NZCA 509.

NZ, Crimes Amendment Bill (No 2), April 2011, 49th Parliament, online: Parliamentary Library $<$ https://www.parliament.nz/resource/en-NZ/49PLLawBD18821/16e32fbd6baf305e519d81c4272c $95 \mathrm{e} 84 \mathrm{dfc} 4 \mathrm{cc} 1>$.

Mrmitee, "Complaint to Judicial Council of Canada: Public Awareness Re: Judge Rooke" (5 October 2012), online: YouTube <https://www.youtube.com/watch?v=dGdQjknv1kE $>$.

Personal communication with Associate Chief Justice John D Rooke (23 February 2018).

See text accompanying footnotes 24-26.

WorldFreemanSociety, "Dennis Larry Meads - Freeman Alberta-Dean Clifford discusses" (4 October 2012), online: YouTube <https://www.youtube.com/watch? $=\mathrm{mx} 4 \mathrm{nqNuH} 2 \mathrm{QE}>$.

Meads, supra note 1 at paras 134-39, 183-88; Netolitzky, "History," supra note 3 at 627-28; TSAS, "Broadening Our Understanding," supra note 15 at 44; Kent \& Willey, supra note 198 at 327-29; Potvin, supra note 20 at paras 102-34.

See paraclete Edward Jay Robin, "Comments, Regarding the Man John Rooke's Slander, From Minister Edward-Jay-Robin for C.E.R.I." (8 October 2012), online: YouTube <https://www.youtube.com/ watch? $=\mathrm{XV}-\mathrm{iYSnV} 5 \mathrm{AM}>$. 
Belanger emphasized he is different from other OPCA gurus. They operate in a "commercial" realm, though Belanger does endorse the O'Collins critique of Meads. Belanger has received money, but he does not teach for profit. He complained Meads intimidates and defames those who are attempting to "practice their faith in Christ." Belanger concluded this video with the promise that he and 50 others would shortly file a lawsuit charging Associate Chief Justice Rooke and others for "treason, sedition and blasphemy." That, of course, never happened.

Meads surveys decisions that reject that bible- or religion-based concepts have supraconstitutional status. ${ }^{234}$ Belanger does not acknowledge or respond to that.

An interesting pattern links these OPCA leaders' responses to Meads. First, their ripostes are non-responsive. No substantive legal analysis or rebuttal was conducted, nor were (allegedly) correct and superior authorities identified. Instead, Meads is purportedly invalidated either by recourse to secret law and language (O'Collins, Dove) or by political statements, unsubstantiated allegations of corruption and conspiracy, and claims of moral superiority (Menard, Clifford, Belanger).

The rank-and-file Freeman response was equally haphazard, shallow, and more reliant on sloganeering than any substantive analysis. One representative example is an Internet forum discussion on the World Freeman Society website titled "TO ALL FREEMEN/WOMEN WE NEED TO DECONSTRUCT MEADS VS. MEADS TO ENSURE OUR FUTURE GROWTH AND SURVIVAL."235 While the original poster stressed a need to research Meads and the jurisprudence it identifies as precedents, discussion immediately devolved into allegations that conventional courts lack authority or are corrupt, bald statements of pseudolaw, and claims that certain gurus offer authoritative responses. The O'Collins OPCA re-definition text was one such example. ${ }^{236}$ The discussion ultimately turned to the "claim of right" motif, but no one identified that this language appears in the decisions that Meads had compiled. ${ }^{237}$

The remnants of the largely defunct Detaxer community did not publicly comment on Meads. That may be because the jurisprudence and concepts collected in Meads were already known to that population, given their more intellectually rigorous and research-oriented approach to pseudolaw subjects. ${ }^{238}$ The Detaxers were also personally the subjects of much of the case law Meads had compiled.

Pseudolaw litigants attempt to dodge Meads, which also illustrates no meaningful rebuttal or reply has emerged. They disclaim being OPCA litigants ${ }^{239}$ and argue the decision is only

$234 \quad$ Meads, supra note 1 at paras 276-85.

235 Formerly hosted online: $<$ worldfreemansociety.org/forum/43-general-discussion/110014-to-all-freemenwomen-we-need-to-deconstruct-meads-vs-meads-to-ensure-our-future-growth-and-survival $>$. Supra note 209.

237 See e.g. Szoo', supra note 130; Papadopoulos v Borg, 2009 ABCA 201 at paras 3-4; Mercedes-Benz Financial v Kovacevic, [2009] OJ No 783 (QL) at paras 12-13, 39-43, 58 (Sup Ct); Mercedes-Benz Financial v Kovacevic, [2009] OJ No 888 (QL) at para 14 (Sup Ct); ANB, supra note 130 at paras 48-51; $R$ v McCormick, 2012 NSCA 58 at para 8.

238 Netolitzky, "Family," supra note 2 at 993; Netolitzky, "Lawyers," supra note 33 at 441-48.

239 Holmes, supra note 127 at para 22; Crossroads, supra note 70 at para 22; Steinkey v R, 2017 FC 124 at para 5. 
obiter $^{240}$ or should be disregarded. ${ }^{241}$ Other criticism is more dramatic: Meads is "a 200 page decision of treasonous diatribe," 242 or an intentional fraud against all humanity, and therefore "NULL and VOID, ab initio, nunc pro tune, ad infinitum." ${ }^{243}$ Obviously, these OPCA litigants are simply unable to supply any substantial defence or criticism, and so have only one recourse: ungrounded, though theatric, complaints.

This leads to another question — has Meads actually affected the behaviour of persons interested in pseudolaw, one intended audience of that decision? ${ }^{244}$ This is a nuanced issue. Persons who use or express interest in pseudolaw are a complex population with a range of different and distinct characteristics and objectives. ${ }^{245}$

Some are chiefly motivated by the promised results ${ }^{246}$ and are (at least to some degree) rational actors who predictably abandon OPCA concepts once the failure of those ideas is exposed. Meads is very likely an effective deterrent to this subpopulation. $R$. v. Biever ${ }^{247}$ describes one such results-oriented OPCA litigant, a criminal accused facing bank robbery charges. After he reviewed Meads, Biever abandoned Coronation Oath OPCA arguments ${ }^{248}$ that promised a "get out of jail free" release. Biever concluded these ideas had no merit, and were "ill-advised."

Other "mercenaries" are so blinded by greed that they may have little interest in the quality of their "means to an end," at least until it is too late. ${ }^{249}$

Ideology and intensely held beliefs motivate some OPCA affiliates. Perry, Hofmann, and Scrivens provide a detailed typology of the Freeman-on-the-Land community, which includes persons who have "constructed an alternate/fantastical reality or frame of reference that disconnected from the way in which the real world operates." ${ }^{250}$ Some combine that with anti-state and anti-institutional conspiracy theories. Another subclass described in this paper are "The Committed": persons "fully invested in the ideology and practice of anti-authority activism." $" 251$ These subgroups are unlikely to abandon their beliefs in the face of logic, conventional authority, and even persistent in-court failure. ${ }^{252}$

\section{Crossroads, ibid at paras 32-46.}

$241 \quad$ McDougald, supra note 98 at para 13

$242 \quad$ Hartloff, supra note 178 at para 19.

243 Pomerleau, supra note 9 at paras 48-49.

244 Meads, supra note 1 at paras 6, 663-68.

245 See footnotes 16-17.

Netolitzky, "Attack," supra note 17 at 179-81; TSAS, "Broadening Our Understanding," supra note 15 at 38-39; Netolitzky, "Lawyers," supra note 33 at 430-34.

$247 \quad 2015$ ABQB 301 at para 31.

248 Biever had received a literal samizdat circulating in Alberta remand centres that describes theories of a UK OPCA guru John Anthony Hill, or "JAH," online: < http://jahtruth.net/>. See also Rothweiler $v$ Payette, 2018 ABQB 399 at paras 60-65. Hill claims the Stone of Scone was never recovered after it was stolen by Scottish nationalists in 1950. The present Coronation Stone/Stone of Scone is a counterfeit. Hill argues that Queen Elizabeth II was aware of that substitution; her coronation in 1953 was a fraud. That subverts all Commonwealth government and court authority, which devolves into a post-Elizabethian chaos. JAH also indicates that the Queen's failure to execute homosexuals and witches is further evidence of her defective authority. See e.g. most participants in the 2008-2010 Fiscal Arbitrators Detaxer scam: Netolitzky, "Lawyers," supra note 33 at 430-34.

TSAS, "Broadening Our Understanding," supra note 15 at 35-37.

Ibid at 41 .

Adam Christian Gauthier is an excellent model example: Crossroads, supra note 70; Starr, supra note 40; Re Gauthier, supra note 9; Re Gauthier, 2017 ABQB 673; Re Gauthier, 2018 ABCA 14; Re Gauthier, 2018 ABQB 99. 
Then there is a question of comprehension. Unlike their more intellectually sophisticated Detaxer and Sovereign Citizen predecessors, the Freemen-on-the-Land exhibit a quite remarkable lack of interest and knowledge around legitimate legal subjects. Worse, at least some OPCA activities are better described as ritual or magic, rather than a rational or systematic process. ${ }^{253}$ By most standards, Freeman belief and conduct seems simply irrational. $^{254}$

This extends to the guru subpopulation. For example, during his 2013-2014 pre-trial detention, Dean Clifford posted a succession of videos for his supporters. In one video Clifford explained he had received a copy of Meads and after a cursory examination, concluded it obviously had no application to him. The front page of the decision read: "Taxpayer did not have personal identity separate from any fictitious 'corporate identity' which affected his liability for tax and other legal purposes, and documents proffered to contrary were ineffective."

Clifford concluded Meads was irrelevant — he is not a taxpayer. ${ }^{255}$ The quoted sentence is not found in Meads, but was part of a badly drafted headnote attached to the Carswell Canada version of this judgment. ${ }^{256}$ Despite Clifford's frequent and expansive claims of legal expertise, he had no idea what a headnote was, and why it was irrelevant.

While first generation Freeman gurus such as Menard and Clifford simply ignored or denied the validity and application of Meads, some of their successors now acknowledge that decision and recommend avoiding practices and concepts condemned in Meads. For example, "John Spirit" ${ }^{257}$ reviews OPCA indicia and concepts denounced in Meads. ${ }^{258}$ Spirit references Meads ${ }^{259}$ to conclude (correctly) that the Canadian Charter of Rights and Freedoms ${ }^{260}$ may provide a mechanism to challenge government action and legislation. ${ }^{261} \mathrm{He}$ then, however, builds a legally incorrect scheme on this foundation and erroneously claims persons can enforce international treaties via section 7 of the Charter. ${ }^{262}$

Netolitzky, “Magic,” supra note 44; Spencer Dew, “'Moors Know the Law': Sovereign Legal Discourse in Moorish Science Religious Communities and the Hermeneutics of Supersession" (2016) 31:1 JL \& Religion 70 at 87-91; Wessinger, supra note 131 at 160; David Griffin, Truth Language: The Pseudolegal Discourse of the Sovereign Citizen Movement (MA Thesis, Cardiff University School of English, Communication and Philosophy, 2017) [unpublished].

Netolitzky, "Lawyers," supra note 33 at 434-41; Netolitzky, "Magic," supra note 44 at 1081-84.

This video is no longer available online. See Quatloos for contemporaneous commentary, Dean Clifford - A Tale of Two Gurus, online: Quatloos! <www.quatloos.com/Q-Forum/viewtopic.php?f=48\&t= 9364\&start $=580 \# \mathrm{p} 172600>$.

Ibid. The entire bungled headnote only identifies Dennis Meads as "Taxpayer." One can hardly imagine a worse occasion for so inaccurate a summary, where a case will almost certainly be reviewed by selfrepresented persons seeking a loophole through that decision. Carswell has subsequently replaced "Taxpayer" with "DM": Meads v Meads, 2012 CarswellAlta 1607 (WL Can) (QB). See footnote 126.

See e.g. eternallyaware, "Court and an Individual vs OPCA into MEADS VS MEADS" (29 April 2015), online: YouTube $<$ https://www.youtube.com/watch? $\mathrm{v}=$ GylwrFv6X-U>.

Meads, supra note 1 at paras 266, 411.

Part I of the Constitution Act, 1982, being Schedule B to the Canada Act 1982 (UK), 1982, c 11 [Charter].

See also online: The Place To Think It Through <eternallyaware.com/courts.html>.

Supra note 260. Pomerleau, supra note 9 describes and rebuts Spirit's overall scheme. 
The Freeman movement is now in disorder ${ }^{263}$ and, at least in Canada, appears to be in a decline. Meads has almost certainly been a factor in that, but that decision is one of a number of key developments that have set in motion a broader social response that threatens to condemn pseudolaw to comparative obscurity.

\section{Public Response}

As previously noted, Meads found another, unexpected, audience. The decision is broadly read by members of the general public.

Several facts indicate its broad appeal. The first is that since its release, Meads has been amongst the most accessed court judgments on the CanLII database, which suggests a readership that is broader than the legal profession, particularly since pseudolaw is not a subject relevant to the work of most legal professionals. Each year since its release in 2012, Meads has ranked in the top three most read CanLII decisions, ${ }^{264}$ periodically trading places with Dunsmuir v. New Brunswick. ${ }^{265}$ It seems safe to conclude that no member of the general public would voluntarily read the latter. ${ }^{266}$

Meads appears in discussions in a very wide array of online communities with subjects such as fact-checking, ${ }^{267}$ science fiction, ${ }^{268}$ Internet "Lolcow" personalities, ${ }^{269}$ traffic ticket

Netolitzky, "History," supra note 3 at 639; TSAS, "Broadening Our Understanding," supra note 15 at $16-18,44$.

Colin Lachance, "Have You Read 2012's Top Cases?" (12 December 2012), Slaw (blog), online: $<$ www.slaw.ca/2012/12/12/have-you-read-2012s-top-cases/>; Colin Lachance, "Have You Read 2013's Top Cases?" (12 December 2013), Slaw (blog), online: <www.slaw.ca/2013/12/12/have-you-read2013s-top-cases/>; Colin Lachance, "Have You Read 2014's Top Cases?" (16 December 2014), Slaw (blog), online: <www.slaw.ca/2014/12/16/have-you-read-2014s-top-cases/>; Xavier BeauchampTremblay, “'Five Days of CanLII Stats', Day 1" (17 December 2015), The CanLII Blog (blog), online: <blog.canlii.org/2015/12/17/five-days-of-canlii-stats-day-1/>; Sarah Sutherland, "What Were You Looking at in 2016: CanLII's Top Cases" (21 December 2016), The CanLII Blog (blog), online: $<$ https://blog.canlii.org/2016/12/21/top-cases-2016/>; Sarah Sutherland, "What Were You Looking at in 2017: CanLII's Top Cases" (20 December 2017), The CanLII Blog (blog), online: $<$ https://blog.canlii.org/2017/12/20/what-you-were-looking-at-in-2017-canliis-top-cases/>. Dunsmuir v New Brunswick, 2008 SCC 9.

And neither would most law students, lawyers, or judges, if they could help it. That it is a critical case authority is, of course, obvious.

See How Widely Influential Has Meads v Meads Been in North American Jurisprudence? online: The Straight Dope < boards.straightdope.com/sdmb/showthread.php?t=794280>.

See SovCit, FOTL and Assorted OPCA Nonsense Discussion, online: Sufficient Velocity <https:// forums.sufficientvelocity.com/threads/sovcit-fotl-and-assorted-opca-nonsense-discussion.30983/>; $A$ Truenamer He Ain't, online: Spacebattles < forums.spacebattles.com/threads/a-truenamer-he-aint.239 $893 />$.

269 See OPCAL, Sov Cits, Freemen on the Land Success Thread - How to Avoid Paying Taxes and Win in Court, online: Kiwifarms $<$ https://kiwifarms.net/threads/opcal-sov-cits-freemen-on-the-land-successthread.5850/>. 
review,${ }^{270}$ hockey, ${ }^{271}$ video games, ${ }^{272}$ and even on the notorious " 4 chan. ${ }^{, 273}$ Unsurprisingly, Meads is referenced by "hobbyist" pseudolaw critic communities worldwide. ${ }^{274}$

In many ways, Meads was perfectly timed. Prior to 2012, pseudolaw was all but unknown in Canada at large. Awareness of the Sovereign Citizen, Moorish, Detaxer, and Freeman communities was sequestered in specialized OPCA community and critic sources. However, this was the point that the Freeman-on-the-Land movement first became more visible in mass media, for example via appearances by Freeman gurus, ${ }^{275}$ newspaper reporting, ${ }^{276}$ and even an Edmonton-area theatre play. ${ }^{277}$ Most of this attention was perceived by Freemen in a very negative light; for example "Finding the Freemen,"278 an early 2012 CBC report on The National, met with much criticism as a "hit piece."279

Another highly influential development occurred in 2013 when members of the TSILC/USN OPCA movement engaged in illegal squatting in Calgary and the Grande Prairie area. ${ }^{280}$ TSILC/USN leader Mario Antonacci's attempt to seize his senior-citizen landlady's rental property as the TSILC/USN's embassy garnered much hostile reporting.

See Common Law Dictates That Everyone Has the Free Right to Trav, online: Ontario Highway Traffic Act $<$ https://www.ontariohighwaytrafficact.com/general-talk/common-law-dictates-that-everyone-hasthe-free-right-trav-t4901.html>.

271 See Freemen on the Land Are Growing Exponentially, online: Calgarypuck Forums $<$ https://forum. calgarypuck.com/showthread.php?t=97327\&page $=5>$.

See Topic: Sovereign Citizens: Or, Why Not to Believe Legal Advice on the Internet, online: Hard Light Productions Network $<$ http://www.hard-light.net/forums/index.php?topic $=85677.0>$. See online: 4 plebs $<$ https://archive.4plebs.org/pol/thread/33456426/>; <http://archive.4plebs.org/pol/ thread $/ 25269242 />$.

This occurs in both "mainstream" skeptic/critic forums (see e.g. Creating an Online Resource on Sovereign Citizens, online: The Fogbow $<$ thefogbow.com/forum/viewtopic.php? $\mathrm{f}=26 \& \mathrm{t}=8651 \& \mathrm{p}=$ 743263>; Organized Pseudolegal Commercial Arguments, online: Quatloos! <www.quatloos.com/QForum/viewtopic.php?f $=48 \& \mathrm{t}=8805>$; Doppelpunkt-Namen? online: Sonnenstaatlandforum $<\mathrm{https}: / /$ forum. sonnenstaatland.com/index.php?topic $=4304.0>$ ) and by observers in "alternative" communities (see e.g. Kyle Rearden, "Meads v. Meads, 2012 ABQB 571 [Canadian Court Case]" (2 February 2014), The Last Bastille (blog), online: <https://the lastbastille.wordpress.com/2014/02/02/meads-v-meads2012-abqb-571-canadian-court-case/>).

See e.g. Adrienne Arsenault, "Finding the Freemen," CBC News (29 February 2012), online: $<$ www.cbc.ca/news/canada/freemen-movement-captures-canadian-police-attention-1.1262159>; Dean C Clifford, "CBC Radio The Current with Anna Maria Tremonti Interviews Dean Clifford" (8 February 2016), online: YouTube $<$ https://www.youtube.com/watch?v=3SqqeHrDny4 $>$; ShawTVSouthVI, "Dean Clifford, Canadian 'Freeman' - Shaw TV Victoria" (5 July 2013), online: Youtube <https://www. youtube.com/watch?v $=1 \ln 94$ zgo $7 \mathrm{i} 0>$.

See e.g. Stewart Bell, "Free for All; Just What is it That Freemen Have Against Government?" National Post (30 October 2010) A1; Vik Kirsch, "Tight Security for 'Freeman' Hearing; Visitors to Courtroom in Bail Proceedings Searched," Guelph Mercury (6 March 2012) A3; Douglas Quan, "Freeman on the Land Movement Creates 'Major Policing Problem:' Spy Agency," Vancouver Sun (29 December 2012) B3; Robert Koopmans, “Freeman' Says He's Above the Law," Kamloops Daily News (24 December 2010) A3.

Liz Nicholls, "Free-Man Gets an Overhaul; Exploration of Freedom More Fun, Cohesive," Edmonton Journal (19 January 2013) E4. Arsenault, supra note 275 .

279 See e.g. thetruthergirls, "CBC 'Finding the Freemen' Hit Piece" (8 March 2012), online: YouTube $<$ https://www.youtube.com/watch? v=_Bzvdy6tuil >; Press For Truth, "CBC's Hit Piece on the Freeman Movement (pressfortruth.tv)" (2 March 2012), online: YouTube <https://www.youtube.com/ watch? $v=8 \mathrm{jzZW}$-LijPM $>$; ttswakingminds, "GRASSHOPPERMEDIA Critical Review of 'Finding the Freemen' CBC The National report" (5 March 2012), online: YouTube <https://www.youtube.com/ watch?v=tOErCne6BSo>; Tom J Kennedy, "What the 'Freemen' Really Want" (1 March 2012), The UsuryFree Eye Opener (blog), online: <http://usuryfree.blogspot.ca/2012/03/what-freemen-reallywant.html>.

280 Netolitzky, "History," supra note 3 at 628-29; TSAS, "Broadening Our Understanding," supra note 15 at $54-55$. 
These developments, including Meads, helped establish a negative and hostile public perception against pseudolaw and its practitioners. In Canada, the Freemen's willingness to take full advantage of Canadian social benefits but ignore their legal obligations soon led to a popular but derogatory nickname: "Freeloaders-on-the-Land.",281

More recently, Sovereign Citizens, Freemen, Moors, and Reichsbürgers have achieved another dubious distinction. These communities and their ideas are perceived as a socially sanctioned target for legitimate online ridicule. The "amibeingdetained" subreddit is a particularly refined illustration. ${ }^{282}$ Users in this popular subreddit collect online instances of pseudolaw-related documents, written judgments, news reports, but particularly videos that illustrate the typically one-sided engagements between pseudolaw practitioners and law enforcement and the courts. These videos are very broadly viewed. Some encounters, such as between Sovereign Citizens and Idaho bailiff P. Barnes ${ }^{283}$ and Florida judge John Hurley, ${ }^{284}$ have made their "protagonists" notorious. The playful mockery in the amibeingdetained subreddit exhibits both an understanding of, and complete disdain for, OPCA ideas.

Pseudolaw, not unlike Scientology, has become an object of ridicule for online communities. That does not bode well for those who seek to sell these ideas for profit. Any large-scale adoption of pseudolaw in Canada now seems unlikely. That said, the situation in the US is not so certain. ${ }^{285}$

\section{E. MEADS' SOCIAL EFFECT}

Despite these setbacks, announcing that the current Canadian Sovereign Citizen-derived memeplex of pseudolaw is on an inevitable road to extinction is clearly premature. The US experience, where pseudolaw has persisted for at least half a century, ${ }^{286}$ strongly suggests that the promises of being able to ignore the state, get free money, and to live as you please, have an enduring appeal to certain persons. Sociologist Stephen Kent links surges of interest in pseudolaw to periods of social and economic distress. ${ }^{287}$

\footnotetext{
Netolitzky, "History," ibid at 639; Netolitzky, "Family," supra note 2 at 960.

See Am I Being Detained, online: reddit < https://www.reddit.com/r/amibeingdetained/>.

See momamedienta, "Raw Footage of Kootenai County Courthouse Tasing Incident" (23 August 2012), online: YouTube $<$ https://www.youtube.com/watch?v=Ldcx vswa4o $>$.

See AllLivesMatter, "Judge Hysterically Owns a Sovereign Citizen” (5 August 2016), online: YouTube $<$ https://www.youtube.com/watch?v=VnSd-E3Hb3Y >.

Brian S Slater, Sovereign Citizen Movement: An Empirical Study on the Rise in Activity, Explanations of Growth, and Policy Prescriptions (MA Thesis, Naval Postgraduate School, 2016) [unpublished], online: Calhoun $<$ calhoun.nps.edu/bitstream/handle/10945/50485/16Sep_Slater_Brian.pdf $>$ observes at $61-65$ that pseudolegal and conspiratorial perspectives are not so unusual in the modern highly polarized US political environment. 
Pseudolaw will also predictably persist as part of the collection of suppressed, broadly rejected, and obsolete ideas that social scientists call the "cultic milieu"288 and "occulture."289 This "stigmatized knowledge" provides the raw materials for conspiratorial cultures. ${ }^{290}$

OPCA beliefs have been described as a "disease of ideas." 291 There is little question that the Canadian public has rejected pseudolaw. Instead, exposure to these ideas seems to have had the opposite effect; they are a subject for public derision. Much like their biological analogues, exposure to OPCA pathogens leaves behind immunity to pseudolaw and a belief that one can "cheat code" around state and court authority. Meads has been important in that process, both in Canada and other countries.

Nevertheless, these OPCA ideas will probably endure to some extent, hosted by marginal anti-government communities. Some pseudolaw appears to operate as magic. ${ }^{292}$ There is no obvious way to dissuade the "re-enchanted" practitioners of these ideas. The Sovereign Citizen pseudolaw memeplex will probably remain sequestered within the insular, inwardlooking populations that currently hold these ideas, and other equally marginalized, but, as of yet, "uninfected" groups. Perry, Hofmann, and Scrivens observe that some OPCA affiliates seek to isolate themselves from general society. ${ }^{293}$ These "escapists" may succeed in forming detached communities, perhaps even multigenerational ones. Similarly, the gurubased structure and revelatory character of OPCA movements might result in stable cult-like groupings, ${ }^{294}$ particularly if centred on an effective charismatic leader. ${ }^{295}$

The OPCA phenomenon and Meads will therefore likely remain relevant for courts, law enforcement, and, to some extent, lawyers. However, to the Canadian mainstream, those who practice pseudolaw will be little more than disaffected extremists, kooks, and the subject of mockery.

\section{Meads Illustrates Trial COURT EXPERTISE}

Conventionally, appellate courts and legal academics are ascribed higher or elevated degrees of expertise in legal topics. There are good reasons for that. Appellate courts, after all, decide what is and what is not the law. Subordinate tribunals are then bound by stare decisis. Appeal proceedings occur before a panel of judges, which, in theory, provides the advantage of multiple perspectives, discussion, debate, and reflection. The Supreme Court of Canada receives submissions from interveners and permits reference to social science evidence, particularly during Charter-related litigation. Law academics have the time and

Colin Campbell, "The Cult, the Cultic Milieu and Secularization" in Michael Hill, ed, A Sociological Yearbook of Religion in Britain 5 (London: SCM Press, 1972) 119 at 119-36.

Christopher Partridge, The Re-Enchantment of the West: Alternative Spiritualties, Sacralization, Popular Culture, and Occulture, vol 2 (London: T\&T Clark International, 2005) at 62-86.

Michael Barkun, A Culture of Conspiracy: Apocalyptic Visions in Contemporary America, 2nd ed (Berkeley: University of California Press, 2013) at 26-38.

Netolitzky, "Pathogen," supra note 140 at 3-4. See also Netolitzky, "History," supra note 3 at 611; Netolitzky, "Family," supra note 2 at 994-96.

See footnote 253.

TSAS, "Broadening Our Understanding," supra note 15 at 37-38.

Kent \& Willey, supra note 198, identifies parallels between cults and OPCA movements.

TSAS, "Broadening Our Understanding," supra note 15 at 46-47, 62-63. 
resources to become particularly familiar with certain domains and subjects. That allows them to offer both deep and longitudinal commentary on subjects of particular interest.

However, this preconception that appeal courts and academics bring special expertise fails in certain circumstances. Meads illustrates that. The OPCA phenomenon usually arises in trial courts. Many, if not most, OPCA proceedings do not result in a reported judgment. OPCA disputes rarely go to appeal, ${ }^{296}$ and when they do, those matters are often denied leave ${ }^{297}$ or the pseudolaw deployed is disposed of in a perfunctory manner. ${ }^{298}$ That is entirely appropriate. After all, there is no legal substance to these concepts.

Another reason why OPCA issue appeals are less common is certain pseudolaw theories distinguish between "common law" versus "statutory" courts, the latter in OPCA folklore being illegitimate or a trap that creates state jurisdiction. Some OPCA litigants reject appeal courts as invalid on that basis.

In any case, the net effect is that expertise in OPCA litigation has accumulated with trial judges and litigators in certain specific topic areas. ${ }^{299}$ This expertise has relatively little to do with the law itself, since pseudolaw litigants do not argue or advance law. Rather, the complicated character of OPCA litigants and their court activities is entirely tangential to conventional legal processes and issues, with the potential exception of questions of procedural fairness. ${ }^{300}$

That, however, does not mean pseudolaw is not a problem. These ideas invite conflict with state authorities, ${ }^{301}$ and are a time-consuming waste of critically limited judicial resources. Worse, and this is a fact which receives far too little attention, OPCA litigation is often selfdestructive. ${ }^{302}$ There is a wry quip among Sovereign Citizen and Freeman observers: "There is no better way to transform a $\$ 50$ traffic ticket into a stay in jail!" ${ }^{103}$ Sadly, this is the truth. Again, this self-injury occurs largely in trial processes, and trial courts are therefore better positioned to develop tools to intervene, and, preferably, minimize damage of this kind.

A related unusual aspect of Meads is that the decision collected information. Meads is sometimes characterized (or criticized) as a decision that is substantially obiter dicta ${ }^{304} \mathrm{In}$

Scotland might be an exception. The high court of that jurisdiction, the Scottish Court of Sessions, has heard at least two OPCA appeals: McLeod v Prestige Finance Ltd, [2016] CSIH 87 (Scot) (the WeRe Bank) and Wilson, supra note 96 (the "promissory notes are cash" motif).

The author has identified 51 Supreme Court of Canada leave applications that appear to involve OPCA subjects. All were denied leave.

See e.g. $R v$ Nicholson, 2016 ONCA 677.

See footnote 5 .

See e.g. $R v$ Jefferd, 2016 BCSC 1463.

Netolitzky, "Attack," supra note 17 at 174-75; Netolitzky, "Family," supra note 2 at 967; TSAS, "Broadening Our Understanding," supra note 15 at 40-42.

Netolitzky, "History," supra note 3 at 641-42; and for example, Parlee, supra note 9 at paras 1, 83-84; Pomerleau, supra note 9 at paras 158-59; McDougald, supra note 98 at paras 63-65.

Or worse, serious harm and criminal charges. See e.g. Jesse Feith, "Longueiul Man Involved in Police Chase That Injured Woman Is Denied Bail," Montreal Gazette (27 November 2018), online: <https:// montrealgazette.com/news/local-news/longueuil-man-involved-in-police-chase-that-injured-woman-isdenied-bail $>$.

See e.g. "Meads vs Meads = Orbiter Dicta = Non-Binding Opinion" (5 May 2015), online: Sue Wrongdoers $<$ member.suewrongdoers.com/meads-vs-meadsorbiter-dictanon-binding-opinion $/>$. This website is operated by Paradigm Education Group educator turned guru Michael Millar, who recently was sentenced to 2.5 years in jail for teaching pseudolaw concepts: $R$ v Millar, 2017 BCSC 323 . 
a technical sense, that is arguably true, if one uses the definition that any finding of fact and law outside the rationale used to reach a decision, the ratio decidendi, is obiter, surplusage, and therefore may safely be ignored. That said, in Canada, judicial commentary outside the exact facts and law applied to dispose of a case does have a variable and contextual influence and effect. ${ }^{305}$

While Meads does address issues, laws, and facts that are not reflected in Dennis Meads' materials and arguments, most of the decision is relevant within the broader context of how to evaluate and reject the pseudolegal effect of Meads' unusual in-court conduct, statements, and documentation. ${ }^{306}$ Could the decision have been abridged and still adequately respond to and defeat Meads' materials and arguments? Yes, without question! However, a claim that the wider inquiry that occurred was unrelated to Meads is simply incorrect. Without that context, Meads is a bizarre, inexplicable actor, a caricature of vexatious litigation.

As mentioned, what is atypical here is that the Alberta Court of Queen's Bench engaged in what might be described as collecting activities. Meads compiled and synthesized facts about this unusual type of litigant and litigation based on reports in other decisions and unreported experiences of that Court. Similarly, the Court identified and grouped jurisprudence that related to this subject area. Up to that point, these legal principles and litigation history were almost entirely unconnected.

Outside its broad though traditional components, Meads operates as what might be called a "review judgment." That name relates to "review articles" or "review papers," a category of academic publications which collect and summarize previously published studies, rather than reporting on new facts, experimentation, or analysis. Publications of this kind are commonplace in technical subject areas, and are critical cornerstone resources in those disciplines. For example, Annual Reviews ${ }^{307}$ publishes collections of review articles that synthesize research on topical, active, and controversial subjects in economics and the physical and social sciences. Its publications have among the highest impact citation ranks in their topic areas.

The review article concept is one that does not seem particularly developed in law, though, arguably, its function is instead satisfied by legal texts authored by expert lawyers, academics, and occasionally judges. However, those resources tend to have a broad scope and therefore are unlikely to hone in on and summarize a specific development or subject topic in depth. Most papers in law journals instead have a narrower focus than the typical scientific or technical review article.

Does Meads' atypical content then fill a gap in legal literature? Plausibly, yes. Canadian legal academics have exhibited little interest in pseudolaw and its host populations. ${ }^{308}$ Broad-

$305 \quad R v$ Henry, 2005 SCC 76 at paras 52-59.

306 Meads, supra note 1 at paras 146-53, 207-11, 225, 231-33, 238, 253, 265, 270, 277, 285, 333-37, 397-404, 418-20, 427, 432-39, 448-57, 470, 493-511, 515-17, 531-43, 676-729.

See online: Annual Reviews <www.annualreviews.org/>.

Mark Edward DeForrest \& James M Vaché, "Truth or Consequences Part Two: More Jurisprudential Errors of the Militant Far-Right" (1999-2000) 35:3 Gonz L Rev 319 at 320-21 make similar observations concerning US academic commentary. 
based appellate review of this subject is unlikely. Appeal courts can and do screen themselves against all meritless appeals, and not just OPCA litigation.

A trial court decision is therefore the logical mechanism to review a trial-level phenomenon. However, Meads is more than a review of legal principles that debunk pseudolegal fallacies. This decision also puts the OPCA phenomenon into context, and, along with subsequent related cases, provides a toolkit of examples and explanations for what has been encountered to date, and the responses that have (or have not) worked. Resources of this kind could only come from trial courts because those are the "expert bodies" for this kind of litigation activity. That knowledge and experience deserves cautious respect.

\section{What LIES AHEAD}

OPCA litigation is likely to continue in Canada, but, from a trial court standpoint, this phenomenon is now relatively simple to manage. Practitioners of pseudolaw are easy to pick out; their concepts are expertly refuted. Canadian courts ${ }^{309}$ are building an increasingly sophisticated suite of tools to end this vexatious litigation in a timely, cost-efficient manner, such as the Master Order concept, ${ }^{310}$ court access restrictions, ${ }^{311}$ and "show cause" procedures. $^{312}$

Innovation in pseudolaw is rare, and what little occurs remains anchored to cornerstone concepts such as the "Strawman," 313 or are pathetically transparent "money for nothing" schemes. ${ }^{314}$ Unfortunately, that does not address the harm caused to the often gullible and ideologically fixated persons who use pseudolaw and their litigation targets. Court intervention in that sense comes too late to help these victims of OPCA guru conmen.

Is Meads an unusual “one off” experiment? Perhaps not. Meads is plausibly an early example of a new class of expert decision. Arguably, both appeal courts and legal academics have demonstrated little appreciation of day-to-day realities faced by trial courts. These institutions struggle to meaningfully engage the growing number of self-represented persons and increased procedural and constitutional issue complexity, while crippled by critical government failures to maintain adequate court resources and judicial complements. Courts have few ways to shield themselves from abuse. That vulnerability is illustrated by the escalating misuse of habeas corpus by incarcerated and detained persons. These meritless

TSAS, "Broadening Our Understanding," supra note 15 at 53, suggests Meads and other Canadaspecific steps provide advantages over the US in managing OPCA litigation.

See text accompanying footnotes $43-44$.

See generally Unrau v National Dental Examining Board, 2019 ABQB 283 at paras 178-99 [Unrau\#2]. See e.g. Boisjoli, supra note 9; Re Gauthier, supra note 9.

See generally Unrau v National Dental Examining Board, 2018 ABQB 874. See e.g. Rothweiler \#2, supra note 170; DKD (Re) (Dependent Adult), 2018 ABQB 1021, OPCA litigation abandoned 2019 ABQB 26; Labonte v Alberta Health Services, 2019 ABQB 41, actions struck 2019 ABQB 92, court access restricted 2019 ABQB 137; Lemay v Steele, 2019 ABQB 202, action struck 2019 ABQB 304. See Netolitzky, "History," supra note 3 at 633-35; Netolitzky, "Magic," supra note 44 at 1069-78; Pomerleau, supra note 9.

See text accompanying footnotes 52-115. 
applications not only waste court resources, but take priority over legitimate court proceedings. ${ }^{315}$

Another example of these underappreciated struggles faced by trial courts is a mismatch between trial courts' evolved traditional and legislated designed roles, and what they are actually now required to do. For example, conventional expectations of process and evidence fray when a motions judge, on the last week or two before Christmas, faces a courtroom filled with distressed parents who demand the Court issue orders to structure the minutiae of where, in the holidays ahead, children will spend a particular day or meal, transfer schedules and locations, and so on. All that is based on what purports to be affidavit evidence, but instead are stereotypically irrelevancies, opinion, argument, and copious printouts of social media websites, emails, and text messages. Proceedings of this type have nothing to do with law as an appeal court or academic would know it. Yet, this kind of domestic micromanagement is a purportedly "adjudicative" function served by superior courts.

And those are the "fair dealing" SRLs. The increasingly common vexatious litigants reviewed in Unrau \#2 $2^{316}$ are much worse. ${ }^{317}$ This recent decision of Associate Chief Justice Rooke is arguably a further example of a "review judgment."

In this sense, trial courts and traditional expert legal authorities operate in an uneasy relationship which has distinct parallels to the World War I disconnect between frontline soldiers in the mud, wire, and trenches, and their commanding officers, safely ensconced behind the lines in comfortable chateaus, pushing counters around maps. The actual day-today operation of trial courts is often unappreciated by appeal courts and legal academics; these realities are unimaginable to most in those institutions.

This disconnect has a number of implications when it comes to developing law. The first is that trial courts face a range of issues that are of no real interest to appellate bodies, as these cases seldom get there. ${ }^{318}$ OPCA litigation illustrates that. How do you, a judge, communicate with a person who is roleplaying two separate personas? Be careful. A misstep

\footnotetext{
315 Reviewed in Ewanchuk v Canada (Attorney General), 2017 ABQB 237 at paras 170-87; Hamm v Canada (Attorney General), 2019 ABQB 247 at paras 183-270. Additional Alberta examples include: McCargar v Canada, 2017 ABQB 416; Badger v Canada, 2017 ABQB 457; Willis v Attorney General of Canada, 2017 ABQB 540; MacKinnon v Bowden Institution, 2017 ABQB 574, fully struck in 2017 ABQB 654; Gogan v Attorney General of Canada, 2017 ABQB 609; Loughlin v Her Majesty the Queen, 2017 ABQB 677; Lee v Canada (Attorney General), 2018 ABQB 40 [Lee \#2]; Getschel v Canada (Attorney General), 2018 ABQB 409. It ultimately came to light that the deluge of abusive habeas corpus litigation at the Alberta Court of Queen's Bench was at least in part the result of four or more competing "habeas corpus entrepreneurs," inmates preparing habeas corpus materials for profit. See Lee \#2, ibid at paras 205-39, litigant declared vexatious in 2018 ABQB 464 at paras 49-74. Supra note 311.

Vexatious litigation is at least in part a mental health issue: Paul E Mullen \& Grant Lester, "Vexatious Litigants and Unusually Persistent Complainants and Petitioners: From Querulous Paranoia to Querulous Behaviour" (2006) 24 Behav Sci \& L 333; Gary M Caplan \& Hy Bloom, "Litigants Behaving Badly: Querulousness in Law and Medicine" (2015) 44:4 Adv Q 411; Yves-Marie Morissette, "Abus de droit, quérulence et parties non représentées" (2003) 49 McGill LJ 23; Yves-Marie Morissette, "Querulous or Vexatious Litigants, A Disorder of a Modern Legal System?" (Paper delivered at the Canadian Association of Counsel to Employers, Banff, Alberta, 26-28 September 2013) [unpublished]. The "vexatious" label is unfortunate, since that indicates an intention: to "vex." A better approach would focus on the "abusive" operational effect of this litigation: Unrau \#2, ibid at paras 64-68. Or are screened out: see footnote 297.
} 
can result in an expensive and wasteful retrial ${ }^{319}$ when your instructions are reviewed by an appellate court that does not necessarily understand the peculiar realities on the ground. Second, appellate courts often attempt to impose a traditional formal order or structure into what is barely controlled chaos.

Obviously, trial courts cannot, and should not, upset the "hierarchy of courts." However, trial courts, as in Meads and its hypothetical successors, may provide the factual context appeal courts need to better understand "life in the mud and blood." The recent Hryniak $v$. Mauldin, ${ }^{320}$ R. v. Jordan, ${ }^{321}$ and R. v. Cody ${ }^{322}$ decisions indicate the Supreme Court of Canada is re-orienting to emphasize function over form. These decisions instruct that trial courts must develop procedures to unjam a court apparatus that is increasingly dysfunctional. ${ }^{323}$

Ritualistic recourse to procedural formality that might have been achieved in nineteenth century courts fails to recognize the new reality of trial level litigation. In Pintea v. Johns, ${ }^{324}$ the Supreme Court of Canada endorsed the Canadian Judicial Council's Statement of Principles on Self-represented Litigants and Accused Persons, which rejects that court rules of evidence and procedure should be the same for each and every litigant. ${ }^{325}$ That acknowledges the functional mismatch between the influx of SRLs and the procedural formality that is required by common law and legislated court rules. This is part of the new Canadian litigation reality.

The "culture shift" mandated in Hryniak and its successors can only be achieved if appeal courts and legal academics "get their feet dirty," and look objectively at what really goes on in trial courts. ${ }^{326}$ Meads created one such window into the day-to-day reality of trial courts — neither in law nor procedure — but versus the entropic process that Carl von Clauswitz called "friction." 327 Those investigators may be surprised by what they find. There are yet more strange and often troubling things to be found in the field, ${ }^{328}$ not unlike the OPCA litigants who were "surfaced" via Meads.

For example, in Gould, supra note 135, Justice Saunders ordered a retrial on the basis that Russell Porisky, a Detaxer guru, had not had the opportunity to elect a judge and jury trial. With respect to the British Columbia Court of Appeal, an equally plausible explanation is that Porisky was engaged in a "Strawman" double/split person "song and dance." Porisky's attempts to "split" his identity during that proceeding are detailed in the trial judgment: Porisky, supra note 135 at paras 60-61.

2014 SCC 7 [Hryniak].

2016 SCC 27 [Jordan].

2017 SCC 31.

Ibid at paras 37-39; Jordan, supra note 321 at para 139.

Supra note 189.

Supra note 189.

There is much to commend the practice of certain US appeal courts such as the Seventh Circuit, where appellate court judges conduct trials by designation at the district court level.

Carl von Clausewitz, Vom Kriege (Berlin: Ferdinand Dümmler, 1832).

See footnotes 315-16. 
[this page is intentionally blank] 